\title{
Recent Advances in Transition-Metal Catalyzed Oxidative Annulations to Benzazepines and Benzodiazepines
}

\author{
Álvaro Velasco-Rubio, Jesús A. Varela and Carlos Saá* \\ Centro Singular de Investigación en Química Biolóxica e Materiais Moleculares (CiQUS), Departamento de Química \\ Orgánica, Universidade de Santiago de Compostela, 15782 Santiago de Compostela, Spain \\ E-mail: carlos.saa@usc.es
}

\section{Received: ((will be filled in by the editorial staff))}

\begin{abstract}
Benzazepines and benzodiazepines, benzofused seven-membered $N$-heterocycles, compose an important family of natural products and pharmaceuticals. Although certainly important and effectives, classical synthetic methods of these cyclic compounds involve methodologies that often require multistep procedures, with generation of waste materials and lack of sustainability. By contrast, cycloadditions based on transition metal catalyzed $\mathrm{C}-\mathrm{H}$ bond activations (oxidative annulations) have emerged as appealing strategies for more sustainable synthetic processes. In this review, we focus our attention to describe the state-of-the-art transition-metal catalyzed annulations via $\mathrm{C}-\mathrm{H}$ activations to benzazepines and benzodiazepines.
\end{abstract}
1. Introduction
2. Benzazepines via Transition-Metal Catalyzed Oxidative Annulations
2.1. 1-Benzazepines
2.2. 2-Benzazepines
2.3. 3-Benzazepines
3. Benzodiazepines via Transition-Metal Catalyzed Oxidative Annulations
3.1. 1,2-Benzodiazepines
3.2. 1,3-Benzodiazepines
3.3. 1,5-Benzodiazepines
3.4. 2,3-Benzodiazepines
4. Summary and Outlook

Keywords: Benzazepine, Benzodiazepine, C-H activation, Oxidative annulation, Transition-metal catalyst

\section{Introduction}

Seven-membered $N$-heterocycles, azepines, are important skeletal motifs found in numerous natural 4 products and pharmaceuticals. ${ }^{[1]}$ Due to their 5 interesting biological properties, a large number of 6 synthetic methods have been developed to access the 7 azepine nuclei throughout the years. ${ }^{[2]}$ Moreover, the

8 benzofused analogs, benzazepines and

9 benzodiazepines, ${ }^{[3]}$ which compose a wide family of

10 natural products and pharmaceuticals with unique

11 biological activity, have also received considerable

12 attention. $^{[4]}$ The azepine unit can be benzofused from

13 three different sides of the ring (b, c or d) and,

14 therefore, 1-benzazepine, 2-benzazepine or 3-

15 benzazepine integrate the whole benzazepine family

16 (Figure 1). The remarkable biological activity of this

17 family arises from their interaction with specifio5

18 human receptors in the Central Nervous System (CNS),

19 such as $\mathrm{D}_{1}$-receptor (dopamine) ${ }^{[5]}$ or $5-\mathrm{HT}_{1 \mathrm{~A}}$ receptoê6

20 (serotonine), ${ }^{[6]}$ where benzazepines can act either as

21 agonist or antagonist. For instance, Alsterpaullone has

22 been described as a potent antitumoral agent, ${ }^{[7} 27$
23 Galantamine is used to treat Alzheimer' disease ${ }^{[8]}$ and 24 Lorcaserin was approved by FDA to treat obesity. ${ }^{[9]}$

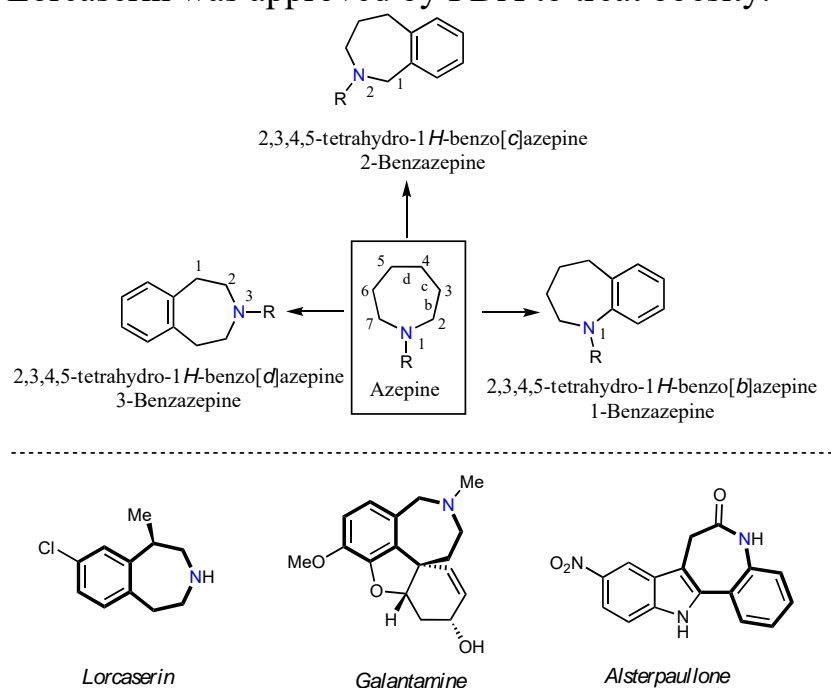

Figure 1. Representative benzazepines

Benzodiazepines, dinitrogenated benzofused members, are classified depending on the relative 
1 position of both nitrogens in the azepine ring as 1,2-,

2 1,3-, 1,4- 1,5- and 2,3-benzodiazepines (Figure 2). ${ }^{[10]}$

3 They are suitable drugs to affect the binding to human

4 receptors such as $\mathrm{GABA}_{\mathrm{A}}{ }^{[11]}$ AMPA (e.g.,

5 Nerisopam) $^{[12]}$, even DNA (e.g., Anthramycin) ${ }^{[13]}$ as

6 well as inhibitors of bromodomains. ${ }^{[14]}$ For instance,

7 1,4-benzodiazepines are one of the most common

8 drugs owing to their extensive use to treat anxiety, ${ }^{[15]}$

9 insomnia, ${ }^{[16]}$ or cancer, ${ }^{[17]}$ 1,2-benzodiazepines are

10 highlighted as cancer inhibitors (e.g., CB-6644), ${ }^{[18]}$

11 and 1,5-benzodiazepines are potent CNS active agents

12 (e.g., Clobazam). ${ }^{[19]}$

13

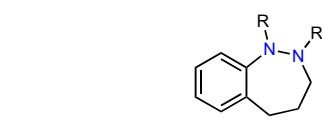

2,3,4,5-tetrahydro- $1 \mathrm{H}$ benzo[c][1,2]diazepine 1,2-Benzodiazepine

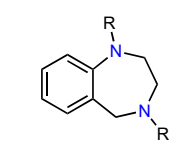

2,3,4,5-tetrahydro- $1 \mathrm{H}$ benzo[e][1,4]diazepine 1,4-Benzodiazepine

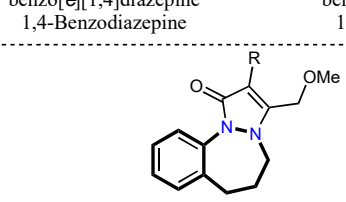

CB-6644 cancer<smiles>[R]=CCNC(=O)CC(C)(CNC(=O)c1cc(Cl)c(F)cc1OCC)OCC</smiles><smiles>Cc1ccc2c(c1O)NC(O)[C@@H]1CC(/C=C/C(N)=O)=CN1C2=O</smiles>

14

Anthramycin
Clobazam
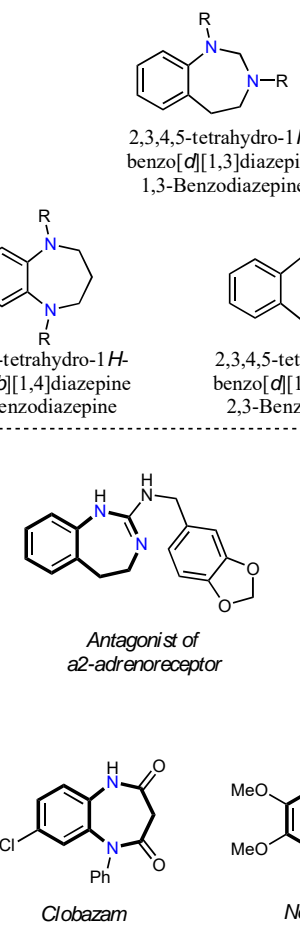

2,3,4,5-tetrahydro- $1 \mathrm{H}$ benzo[d][1,3]diazepine 1,3-Benzodiazepine
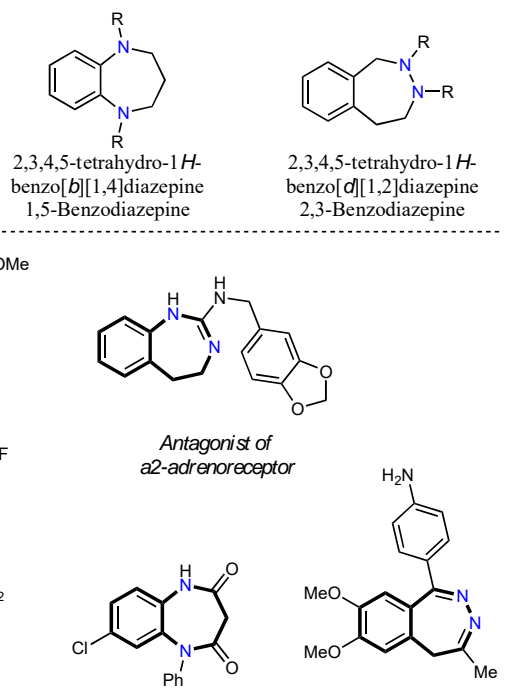

15 Figure 2. Representative benzodiazepines

A large number of synthetic routes to benzazepines

17 and benzodiazepines have been described throughout 18 the last decade ${ }^{[20]}$ the most used are those based on 19 condensations, ${ }^{[21]}$ cyclizations, ${ }^{[22]}$ cycloadditions ${ }^{[23]}$ 20 and ring expansions. ${ }^{[24]}$ All these classical strategies 21 might be considered useful although they usually lack 22 sustainability in their transformations.

23 In a step further toward more sustainable 24 approaches, catalytic methods have been successfully 25 employed to synthesize both benzazepines and 26 benzodiazepines. Thus, transition-metal-catalyzed 27 Heck type reactions, ${ }^{[25]}$ cycloadditions, ${ }^{[26]}$ 28 metathesis, ${ }^{[27]}$ oxidative couplings, ${ }^{[28]}$ intramolecular 29 C- and $N$-aryl(alkyl)ations, ${ }^{[29]}$ tandem processes ${ }^{[30]}$ or 30 hydroamin(d)ation of alkynes ${ }^{[31]}$ has been successfully 31 employed.
Álvaro Velasco-Rubio, born in Salamanca (Spain), received his $\mathrm{BSc}$ in chemistry at the University of Salamanca, Spain, in 2015. He completed his MSc in Organic Chemistry in 2016 for research about transition-metal catalyzed heteroannulations via $\mathrm{C}-\mathrm{H}$ bond activation under the supervision of Profs. Carlos Saá and Jesús A. Varela at Universidad de Santiago de Compostela, Spain. He spent a short research stay at Caltech working on synthetic methodology to access fully substituted $\alpha$-amino ketones under the supervision of Prof. Brian Stoltz. He is currently a fourth year Ph D candidate working on "Sustainable Synthesis of Benzazepines and Benzodiazepines" under the supervision of Profs. Carlos Saá and Jesús A. Varela.

Jesús A. Varela was born in 1971 in Lugo, Spain and studied chemistry at the Universidad de Santiago de Compostela, Spain. He completed his MSc in 1994 and his $P h \quad D$ thesis in 1999 (excellent award) under the supervision of Prof. Dr. Carlos Saá. After a predoctoral research training period in Harvad University under supervision of Prof. Dr. Matthew Shair and a postdoctoral period from 1999 to 2001 as an Alexander von Humboldt and Marie Curie Fellow with Prof. Dr. Paul Knochel at LMU in Munich (Germany), he joined the faculty at the Universidad de Santiago de Compostela as Ramón y Cajal researcher, and since 2008 as Associate Professor. His research interests are focused on organometallic catalysis towards the synthesis of bioactive compounds and molecular materials.

Carlos Saá born in Lugo (Spain), studied chemistry at the Universidad de Santiago de Compostela (Spain) where he received his $P h D$ in 1985 under the supervision of Profs. L. Castedo, R. Suau and J. M. Saá. After postdoctoral studies with Prof. Vollhardt at the University of California, Berkeley, he was appointed as Associate Professor In 1990 at the University of Santiago de Compostela, and since 2004 as a full Professor. His research interest centers on the development of new methodology of organometallic catalysis and their applications to the synthesis of bioactive compounds and organic conductive materials.

The current challenges in transition-metal-catalysis lies in developing more ecofriendly strategies to access highly valuable benzofused seven-membered azaheterocycles. In this sense, annulation reactions, in which two bonds are formed in a single step, are among the most efficient methods for the synthesis of cyclic compounds. ${ }^{[32]}$ Particularly, dehydrogenative 
1 annulation reactions via metal-catalyzed C-HB7

2 activation provide straightforward access to commom8

3 cyclic scaffolds from easily available substrates. ${ }^{[337} 9$

4 Several strategies have been reported to obtain five40

5 and six-membered benzofused azaheterocycles viA 1

6 transition-metal catalyzed $\mathrm{C}-\mathrm{H}$ bond activation, ${ }^{[34]}$ but2

7 few are known for the medium sized seven-membere 43

8 analogs. In this review, the state-of-the-art metal44

9 catalyzed annulations to synthesize benzofused seven 45

10 membered azaheterocycles are highlighted. SynthetiA6

11 strategies, directing groups (DGs) and coupling7

12 partners used to obtain benzazepines and 4

13 benzodiazepines, as well as the mechanism of theset9

14 transformations, will be conveniently discussed. W60

15 have organized the sections according to the type of 1

16 heterocycle and number of atoms involved in the 2

17 annulation.

\section{Benzazepines via Transition-Metal 19 Catalyzed Oxidative Annulations}

\section{$20 \quad 2.1$ 1-Benzazepines}

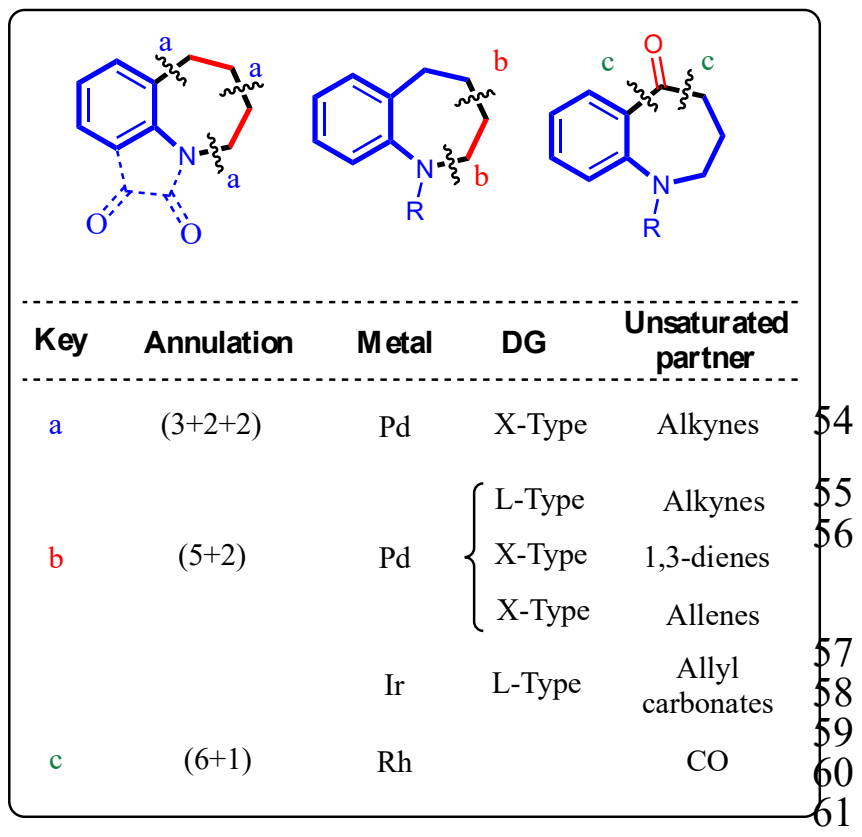

23 Figure 3. 1-Benzazepine disconnections
1-Benzazepines have been synthesized under P\$6 catalysis using nitrogenated substrates bearing L-Typ87 (amines) and X-Type (amides) DGs viø8 multicomponent and standard annulations. ${ }^{[35-40]}$ They69 have been also synthesized under Ir catalysis in a $(5+2) 0$ annulation of $O$-alkenylanilines and allyt 1 carbonates. $^{[41]}$ In addition, a Rh-catalyzed $(6+1) / 2$ carbonylation of $N$-cyclopropylanilides (carbonylative 3 $\mathrm{C}-\mathrm{C}$ activation) rendered benzazepin-5-ones (Figurg 4 3). ${ }^{[42]}$

One of the pioneering examples of multicomponent 6 annulations was reported by Wang and co-workers ing 7 2013. ${ }^{[35]}$ They probed that isatins $\mathbf{1}$, a cyclic anilide 78

\section{3}

type substrate, can react with two equivalents of alkynes 2 to give 1-benzazepines 3 in a formal $(3+2+2)$ cycloaddition (Scheme 1). ${ }^{[36]}$ The authors suggested a mechanism which starts with the ligand exchange to give $\mathbf{I} \cdot{ }^{[35]}$ This is followed by two consecutive 1,2insertions of alkynes to generate the butadienylpalladium intermediate III. Finally, C-H activation (via Concerted Metalation Deprotonation, CMD) led to the eight-membered palladacycle IV, which subsequently underwent reductive elimination to yield the 1-benzazepine 3 . The reaction afforded excellent yields with aromatic alkynes. However, when non-symmetrical alkynes were used, moderate to high yields of a mixture of regioisomers were obtained. The reaction tolerated all types of electrondonating and electron-withdrawing substituents in the aromatic ring of the isatin.
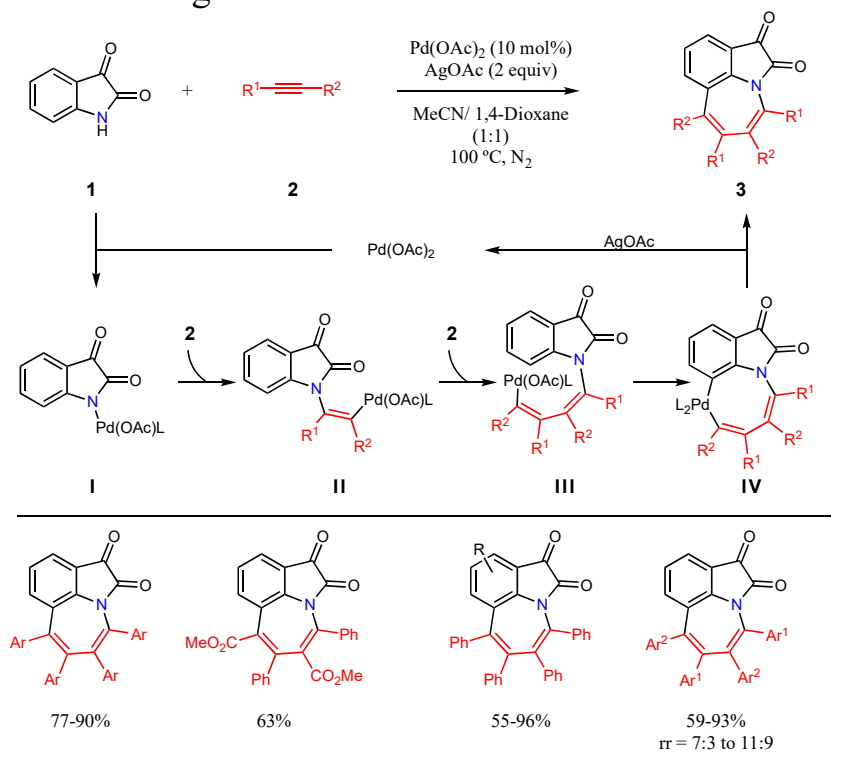

Scheme 1. Pd-catalyzed $(3+2+2)$ annulation of isatins and alkynes to 1-benzazepines.

In 2015, Luan and co-workers reported a Pdcatalyzed $(5+2)$ heteroannulation between $O$ arylanilines $\mathbf{4}$ and alkynes $\mathbf{2}$ to produce dibenzo[b,d]azepines 5 (Scheme 2). ${ }^{[37]}$ The authors proposed a mechanism that is initiated with an anilineassisted (L-type DG) C-H bond activation (via CMD) dimeric complex is broken in the presence of the alkyne to form the coordinated species II that undergo 1,2-migratory insertion into the C-Pd bond to give an eight-membered palladacycle III. Subsequent C-N reductive elimination delivers the enamine dibenzo $[b, d]$ azepine $\mathbf{I V}$ and concomitantly regenerate the $\mathrm{Pd}(\mathrm{II})$ catalyst to restart the cycle. Finally, tautomerization of the enamine to the thermodynamically more stable imine leads to the final dibenzo $[b, d]$ azepine 5. Both aromatic and aliphatic alkynes afforded good to high yields and excellent diastereoselectivities $(>19: 1)$. In the case of nonsymmetrical alkynes, moderate to excellent yields of both regioisomers in modest to good diastereoselectivies were obtained. Furthermore, many 
1 electron-rich and electron-poor substituents in bot226

2 rings of the arylaniline were well tolerated.

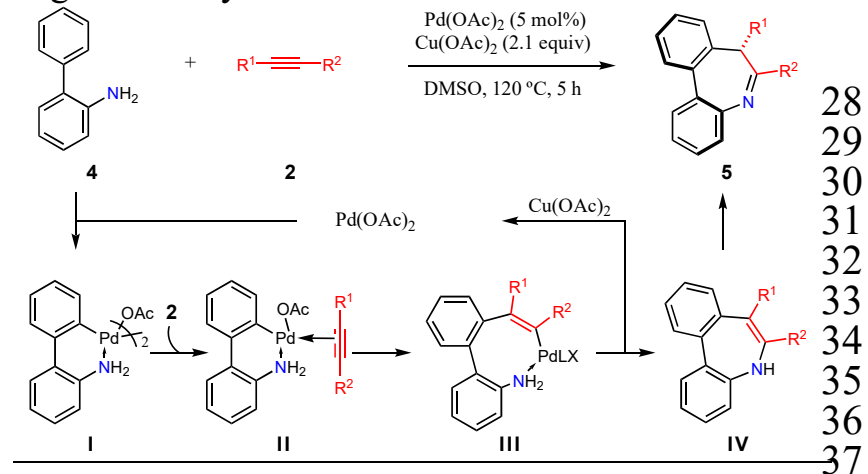

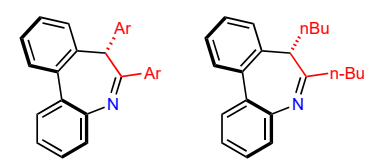

$60-97 \%$

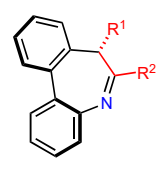

$67-97 \%$ $\mathrm{dr}=10: 1$ to 1.5 :

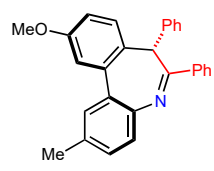

$78 \%$
4 Scheme 2. Pd-catalyzed (5+2) annulation of $o$-arylaniline 45 5 and alkynes to dibenzo[ $[b, d]$ azepines.

6

In 2017, the same group also reported the access to

7 the same core, dibenzo $[b, d]$ azepines 8 , via Pd-

8 catalyzed $(5+2)$ heteroannulation between tosyl

9 anilides 6 and 1,3-dienes (Scheme 3). ${ }^{[38]}$ The

10 mechanism suggested for this transformation involves

11 the initial formation of the six-membered palladacycle

12 I (cis- $\left.-\mathrm{PdX}_{2} \mathrm{~L}_{2}\right)$ via electrophilic palladation. Then,

13 coordination (II) and migratory insertion of the 1,3-

14 diene forms an eight-membered palladacycle III,

15 which is further stabilized with the second double

16 bond of the diene (Pd $\sigma$-allyl complex). Finally, C-N

17 reductive elimination delivers the dibenzo[b,d]azepine

$18 \mathbf{8}$ with concomitant regeneration of the active $\mathrm{Pd}(\mathrm{II})$

19 species to reinitiate the catalytic cycle.

20 Monosubstituted 1,3-dienes gave good to excellent

21 yields of the corresponding 1 - dibenzo[ $b, d]$ azepines as

22 a single diastereoisomer. However, 1,1-disubstituted 48

23 1,3-dienes also worked in good yields, but in a lower

24 5:1 diastereoselectivity.
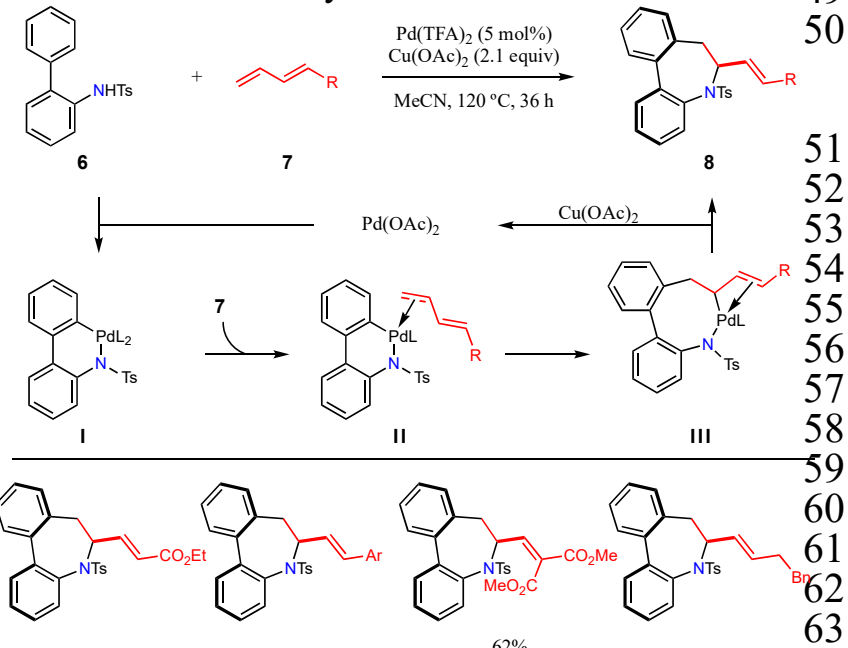

Scheme 3. Pd-catalyzed (5+2) annulation of aryl tosylanilides and 1,3-dienes to dibenzo[b,d]azepines.

Simultaneously, the groups of Mascareñas/Gulías ${ }^{[39]}$ and Zeng ${ }^{[40]}$ reported a Pdcatalyzed (5+2) annulation of ortho-alkenylanilides 9 (triflamides or tosylamides) and allenes $\mathbf{1 0}$ to give 3alkylidene 1-benzazepines 11 (Scheme 4). Mechanistic studies supported by DFT calculations suggested the initial formation of a six-membered palladacycle I through a $\mathrm{C}-\mathrm{H}$ bond activation (via CMD). Then, allene coordination (II) and regioselective migratory insertion into the C-Pd bond forms a $\pi$-allylic palladacycle III, which undergoes reductive elimination to the 1-benzazepine 11 . Oxidation of the resulting $\mathrm{Pd}(0)$ with $\mathrm{Cu}(\mathrm{OAc})_{2}$ and air regenerates the active catalytic $\mathrm{Pd}(\mathrm{II})$ species. Either mono-, di- or tri-substituted allenes give the corresponding 1-benzazepines in good to excellent yields and usually as single isomers. Electronwithdrawing and electron-donating substituents in the aryl ring of the anilide were also well accepted.
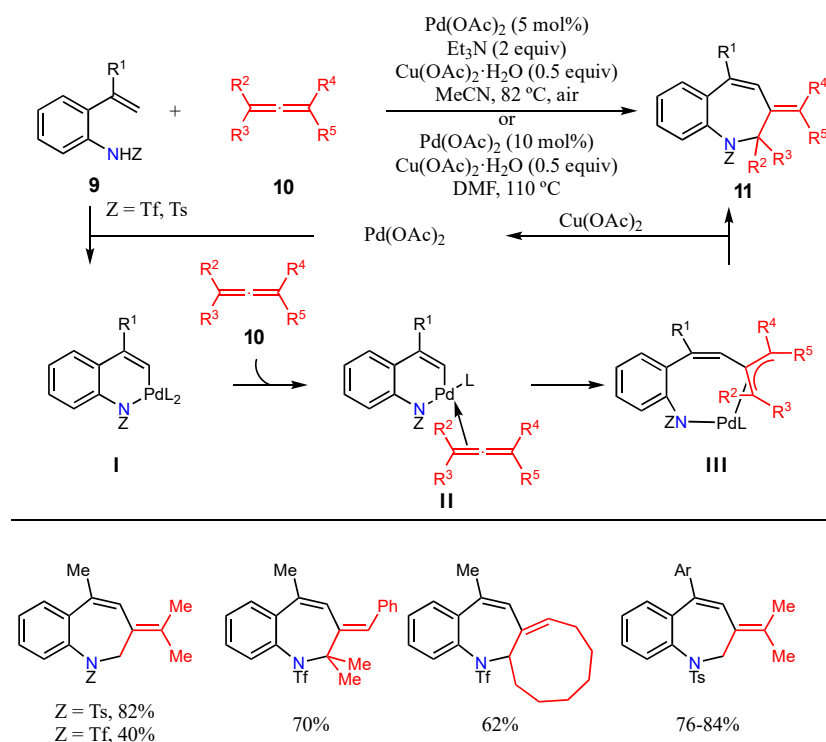

Scheme 4. Pd-catalyzed $(5+2)$ annulation of $O-$ alkenylanilides and allenes to 1-benzazepines.

In 2010, You and co-workers described an Ircatalyzed $(5+2)$ heteroannulation of $o$-alkenylanilines $\mathbf{1 2}$ and allyl carbonates $\mathbf{1 3}$ to 1-benzazepines $\mathbf{1 4}$ in a tandem allylic vinylation/allylic amination reaction (Scheme 5). ${ }^{[41]}$ Furthermore, the allyl-vinyl intermediate I (via $\mathrm{C}-\mathrm{H}$ activation) could be isolated and readily cyclized into the seven-membered azaheterocycle. The tandem reaction afforded $\alpha$-vinyl 1-benzazepines in fairly good yields and excellent enantioselectivities upon employment of phosphoramidites $\left(\mathbf{L}^{*}\right)$ as chiral ligands. Either electron-withdrawing or electron-donating groups were well-tolerated in the 4 and 5 position of the aryl 64 ring. 1,1- Disubstituted styrenes were also efficiently 65 cyclized. 


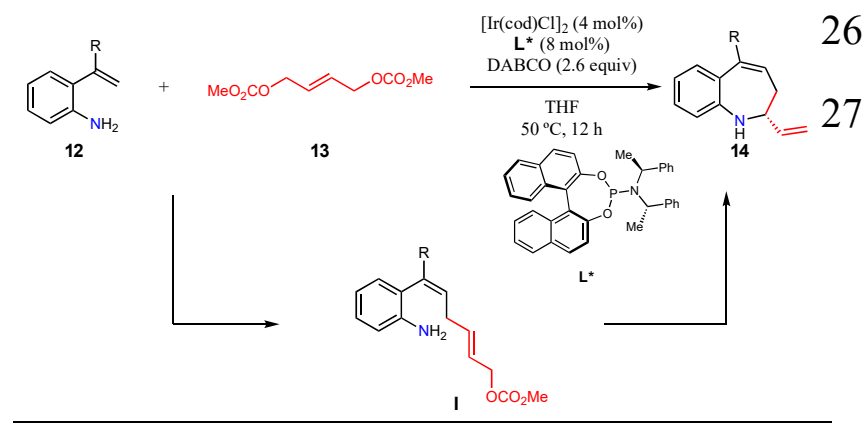

1<smiles>C=CC1CC=Cc2ccc(OC)cc2N1</smiles>
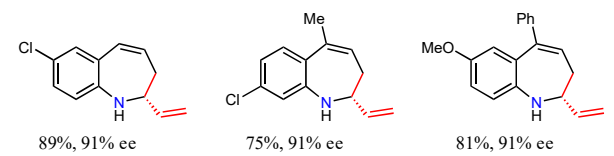

2 Scheme 5. Ir-catalyzed (5+2) annulation of $o$ -

3 alkenylanilines and allyl carbonates to 1-benzazepines.

28

4 In 2018, Bower and co-workers reported a $\mathrm{Rh}$ -

5 catalyzed $(6+1)$ annulation of $N$-cyclopropylanilide 29

615 and $\mathrm{CO}$ (carbonylative $\mathrm{C}-\mathrm{C}$ activation) to

7 benzazepine-5-ones 16 (Scheme 6). ${ }^{[42]}$ The

8 carbonylative cyclization involves a tandem C-C0

9 (carbonylation) / C-H bond activation (Friedel-Craft 31

10 type cyclization) process. The proposed mechanisn 32

11 begins with the C-C bond activation of the 33

12 cyclopropane assisted by the carbonyl group of the 34

13 amide to form the rhodacyclopentanone I upon $\mathrm{CO} 35$

14 insertion. This intermediate subsequently undergoe 36

15 an aryl $\mathrm{C}\left(\mathrm{sp}^{2}\right)-\mathrm{H}$ bond activation to form the bicyclie 37

16 rhodacycle II that, after $\mathrm{C}\left(\mathrm{sp}^{2}\right)-\mathrm{C}\left(\mathrm{sp}^{2}\right)$ reductive $\mathrm{e}^{8}$

17 elimination and protodemetalation, releases the 139

18 benzazepin-5-one 16. Electron-poor and electron-rich40

19 aryl and heteroaromatic rings were well tolerated41

20 Enantioenriched 1-benzazepinones were accesse 42

21 from enantioenriched substrates.
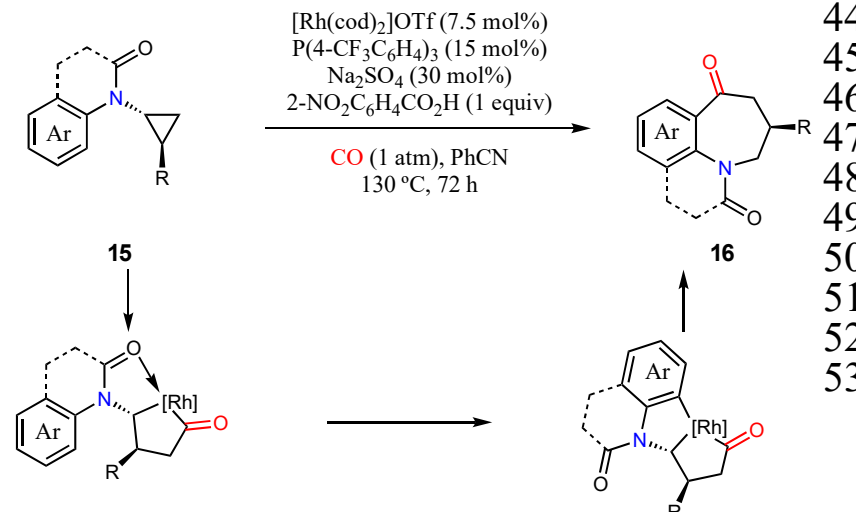

\section{0}

51

52

53

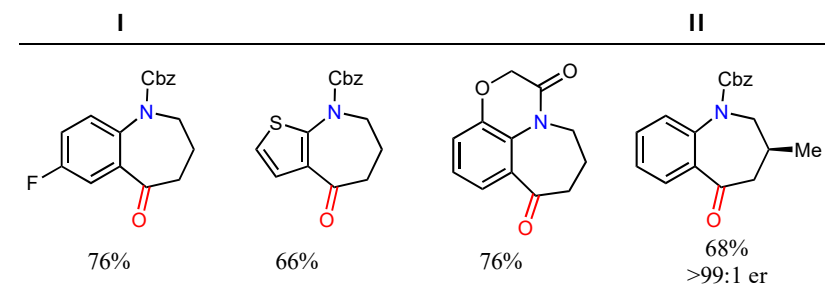

23 Scheme 6. Rh-catalyzed (6+1) annulation of $\mathrm{N}$ -

24 cyclopropylanilides and $\mathrm{CO}$ (carbonylative $\mathrm{C}-\mathrm{C}$ activation)

25 to 1-benzazepine-5-ones.

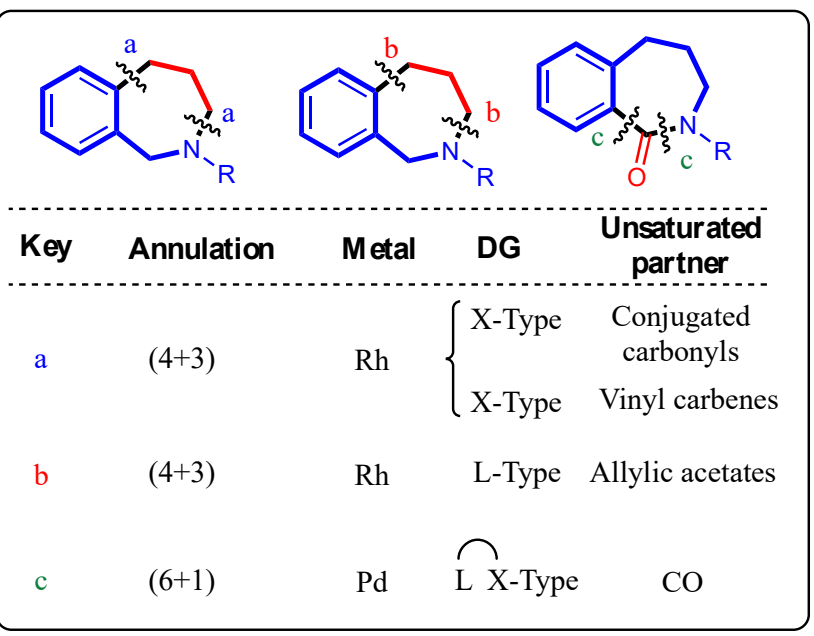

Figure 4. 2-Benzazepine disconnections

2-Benzazepines have been synthesized under $\mathrm{Rh}$ catalysis using nitrogenated substrates bearing either X-Type (amides) DGs via (4+3) annulations or L-type (amines) via intramolecular cyclizations. ${ }^{[43-45]} \mathrm{A}$ Pdcatalyzed $(6+1)$ carbonylation assisted by a bidentate LX-type DG rendered 2-benzazepinones (Figure 4). ${ }^{[46]}$

In 2013, Glorius and co-workers reported a formal $\mathrm{Rh}$-catalyzed $(4+3)$ annulation of benzamides 17 and $\alpha, \beta$-unsaturated aldehydes or ketones 18 to produce 2benzazepinones 19 (Scheme 7). ${ }^{[43]}$ The proposed mechanism involves an initial formation of the fivemembered rhodacycle $\mathbf{I}$ through the coordination of the benzamide to a Rh(III) species to activate the $O$-C$\mathrm{H}$ bond (via CMD). Then, coordination and 1,2migratory insertion of the $\alpha, \beta$-unsaturated compound gives the seven-membered rhodacycle II. After protonation (III) and addition of the N-Rh bond across the carbonyl group, the Rh-alkoxide intermediate IV was obtained. Protonolysis to give the sevenmembered hemiaminal and final dehydration delivers the 2-benzazepinone. Electron-rich and electron-poor benzamides were well tolerated, as well as substituted aldehydes and methyl vinyl ketone, to give moderate to good yields of the corresponding 2-benzazepinones.
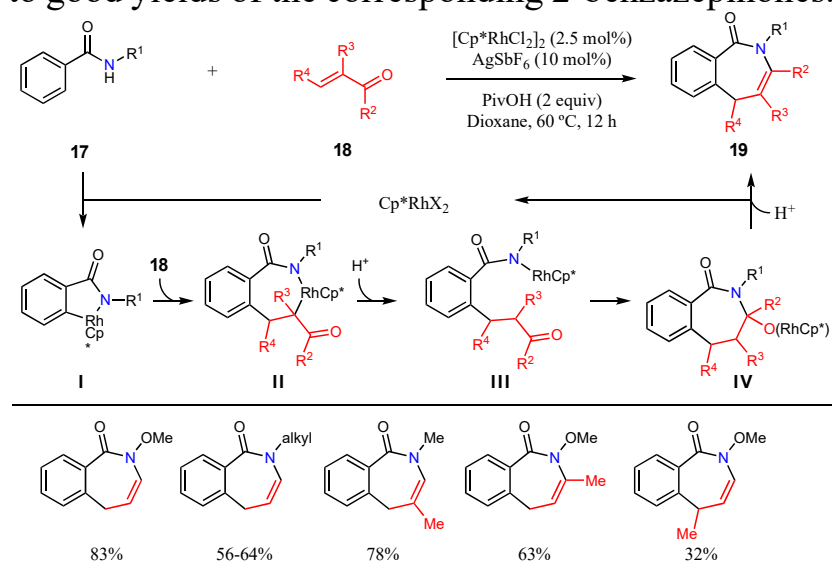
1 Scheme 7. Rh-catalyzed (4+3) annulation of benzamidest4

2 and $\alpha, \beta$-unsaturated aldehydes or ketones to 245

3 benzazepinones.

4 In 2013, Cui and co-workers reported the Rh49 5 catalyzed $(4+3)$ annulation of benzamides 20 an $\$ 0$

6 vinylcarbenoids 21 (Scheme 8). ${ }^{[44]}$ The proposed

7 mechanism involves the initial formation of the five-

8 membered rhodacycle $\mathbf{I}$ through the coordination of

9 the benzamide to activate the $\mathrm{o}-\mathrm{C}-\mathrm{H}$ bond (via CMD).

10 Then, coordination of the vinylcarbenoid followed by

$11 \mathrm{~N}_{2}$ extrusion affords a Rh-carbene that undergoes a

12 1,1-migratory insertion to afford the six-membered

13 rhodacycle II. A subsequent 1,3-allylic migratory

14 insertion generates the eight-membered rhodacycle III

15 that evolves via reductive elimination followed by N-

$16 \mathrm{O}$ bond cleavage to the observed 2-benzazepinone 22

17 with regeneration of the active catalyst. Several

18 electron-rich and electron-poor substituents in the aryl

19 ring of the benzamide were well tolerated. Regarding

20 the vinylcarbenoid, electron-withdrawing groups arø 1

21 necessary to stabilize the carbene and promote the

22 reaction (esters or ketones); alkyl and aryl substituent\$2 23

23 in the olefin were also tolerated.
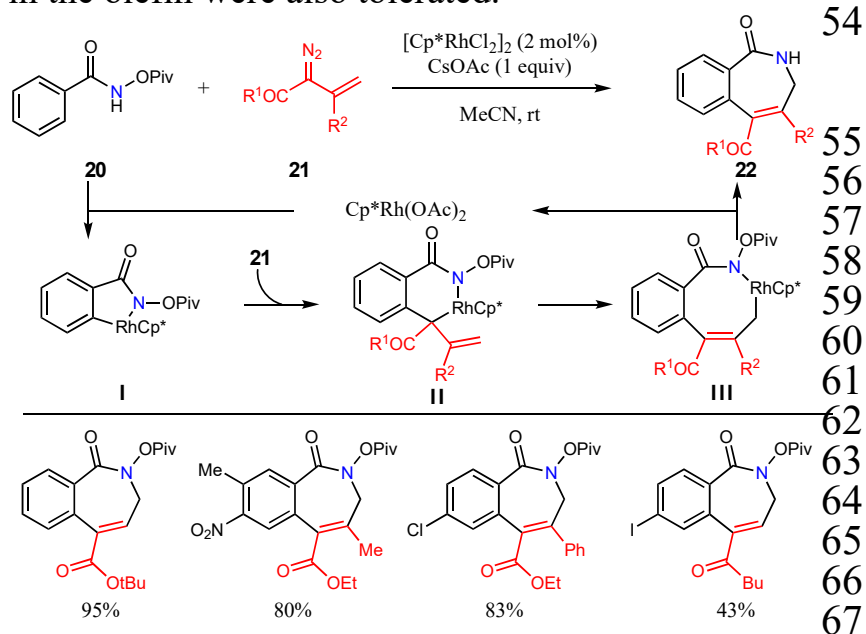

26 and vinylcarbenoids to 2-benzazepinones.

27 In 2018, Kim and co-workers reported the Rh28 catalyzed cyclization of 2-

29 (benzylamino)methacrylates I to form 2-benzazepines

3025 (Scheme 9). ${ }^{[45]}$ The starting substrates were

31 prepared in situ from addition of primary

32 benzylamines $\mathbf{2 3}$ to allylic acetates $\mathbf{2 4}$ derived from

33 methyl methacrylates. As a result, the whole process

34 could be considered as a Rh-catalyzed (4+3)

35 heteroannulation. The proposed catalytic cycle was

36 supported by DFT calculations and mechanistic

37 experiments. The secondary benzylamine coordinates

38 to the $\mathrm{Rh}$ catalyst and undergo $\mathrm{C}-\mathrm{H}$ bond activation II

39 (via CMD). Then, the pending olefin becomes

40 coordinated and subsequently undergoes a migratory

41 1,2-insertion to afford the seven-membered

42 rhodacycle III. Finally, $\beta$-hydride elimination release 1

43 the secondary 2-benzazepine IV (after reductive elimination) with concomitant recovery of the active catalyst in the presence of oxidants to reinitiate the catalytic cycle. A final $\mathrm{N}$-allylation gives rise to the observed tertiary 2-benzazepine 25. A variety of substituents on the aryl ring and at the benzylic position of the starting benzylamine as well as in the allylic ester partner were well tolerated.

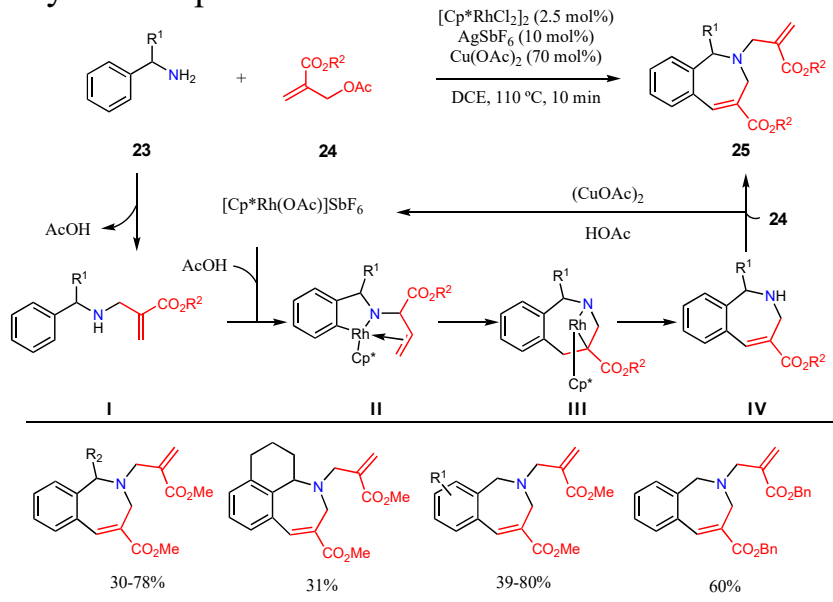

Scheme 9. Rh-catalyzed $(4+3)$ heteroannulation of benzylamines and allylic acetates (from methylacrylates) to 2-benzazepines.

In 2019, Carretero and co-workers reported the Pdcatalyzed $(6+1)$ heteroannulation of $\gamma$ arylpropylamine derivatives $\mathbf{2 6}$ and $\mathrm{CO}$ (Scheme 10). ${ }^{46]}$ The mechanism of the carbonylation, supported by DFT calculations and deuterium-labeling experiments, begins with the formation of the sevenmembered palladacycle I assisted by the chelation of the pyridine (bidentate LX-type ligand). Then, CO ligand exchange takes place (II) to further undergo a 1,1-migratory insertion (III) and reductive elimination to the 2-benzazepinone $27^{[47]}$ with the regeneration of the Pd-active catalyst in the presence of the silver salt and $\mathrm{BQ}$. The reaction tolerated a range of substituted aminoacid derivatives both on the activated aryl ring and on the alkyl chain; simple amines could also be employed instead of aminoacid derivatives.
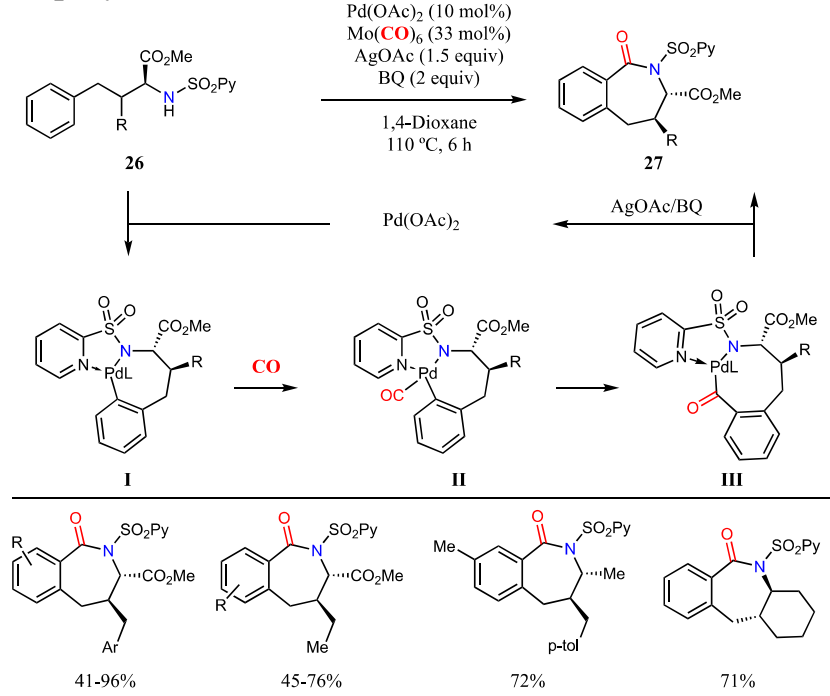
1 Scheme 10. Pd-catalyzed $(6+1)$ annulation of $\gamma$ -

2 arylpropylamine derivatives and CO to 2-benzazepinones.

\section{$3 \quad 2.3$ 3-Benzazepines}

4

5

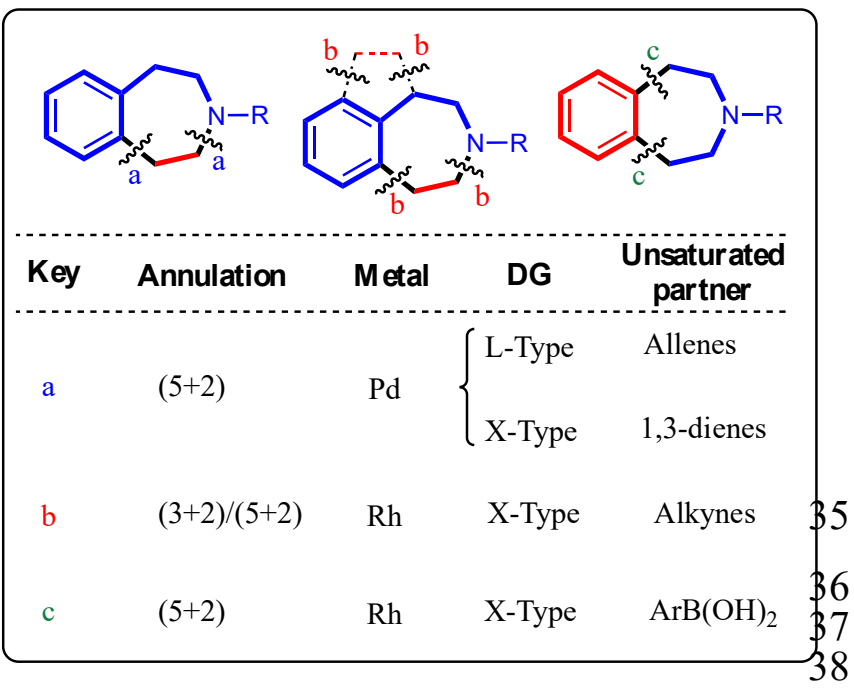

6 Figure 5. 3-Benzazepine disconnections

3-Benzazepines have been synthesized under Pd4

8 catalysis using nitrogenated substrates bearing L-Typq 2

9 (amines) and X-Type (triflamides) DGs via $(5+2) 43$

10 annulations. ${ }^{[48,49]}$ In addition, they have been alsq 4

11 synthesized under $\mathrm{Rh}$ catalysis in a tandem 4

$12(3+2) /(5+2)$ annulation of vinyl iminocarbenes and 46

13 alkynes, ${ }^{[50]}$ and in a formal $(5+2)$ annulation of yne 47

14 enoates and boronic acids (Figure 5). ${ }^{[51]}$

In 2014, Ariza and co-workers reported the $\operatorname{Pd}_{79}^{48}$ catalyzed $(5+2)$ annulation of $\alpha, \alpha$-disubstitute 40 phenethylamines $\mathbf{2 8}$ with allenes $\mathbf{1 0}$ to give $3 \frac{51}{5}$ benzazepines 29 (Scheme 11). ${ }^{[48]}$ The use of $\alpha, \alpha 52$ disubstituted phenethylamines is mandatory for $\$ 3$ successful annulation. The proposed mechanism fo 54 this transformation involves the coordination of the 5 amine to promote the $\mathrm{o}-\mathrm{C}-\mathrm{H}$ activation (via CMD 56 with the generation of the six-membered palladacycles I (trans- $\mathrm{PdX} \mathrm{X}_{2} \mathrm{~L}_{2}$ ). Then, the regioselective insertion of 8 the allene into the Pd-C bond affords the $\pi$-allylisg species II. Finally, an outer-sphere $\mathrm{S}_{\mathrm{N}} 2$ attack by the 80 nitrogen delivers the 3-benzazepine $\mathbf{2 9}$ with the 1 concomitant regeneration of the $\mathrm{Pd}(\mathrm{II})$ active catalys 2

30 the presence of a mixture of $\mathrm{BQ} / \mathrm{AcOH}$. The $\alpha, \alpha_{63}$

31 for a favorable Thorpe-Ingold effect for cyclization.

32 Furthermore, polarized allenes were needed to

33 undergo a regioselective Tsuji-Trost allylic alkylation

34 in moderate to very good yields.
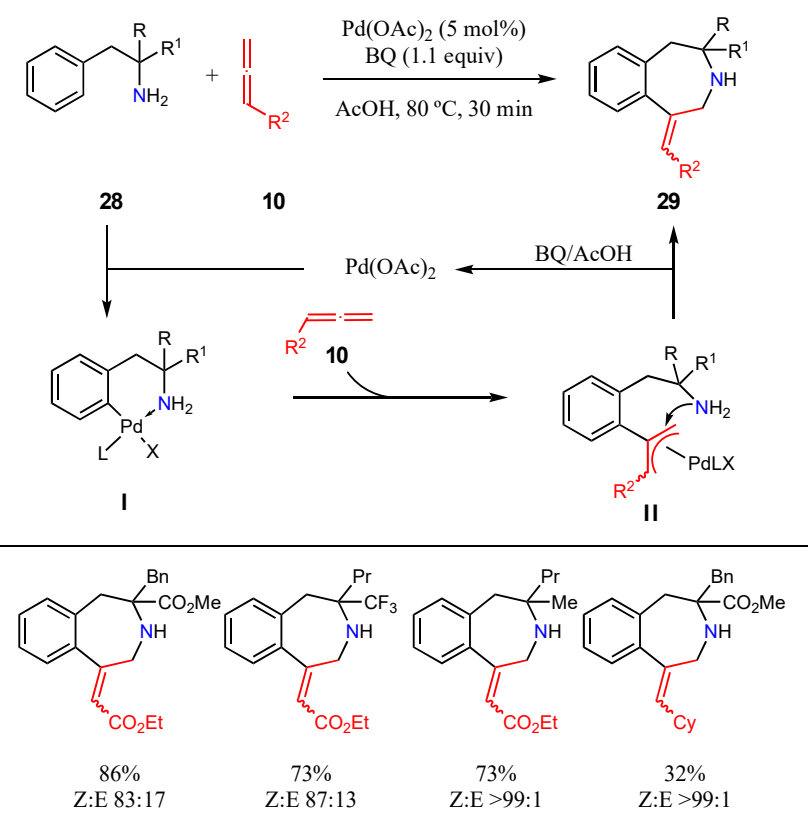

Scheme 11. Pd-catalyzed $(5+2)$ annulation of $\alpha, \alpha-$ disubstituted phenethylamines and allenes to 3benzazepines.

Very recently, Saá and co-workers reported the Pdcatalyzed $(5+2)$ heteroannulation of phenethyltriflamides 30 and 1,3-dienes 7 to yield 3benzazepines 31 (Scheme 12). ${ }^{[4]}$ The proposed mechanism for this transformation was supported by DFT calculations and involves an initial $O-\mathrm{C}-\mathrm{H}$ activation (via CMD) with the generation of the sixmembered palladacycle I (cis- $\left.\mathrm{PdX}_{2} \mathrm{~L}_{2}\right)$. Then, coordination of the less substituted olefin of the 1,3diene followed by a 1,2-migratory insertion yields the $\pi$-allylic intermediate II. The most favored pathway involves the decoordination of the DG from the Pd to form a zwitterionic species III, that subsequently undergoes an outer-sphere $\mathrm{S}_{\mathrm{N}} 2$ attack to render the observed 3-benzazepine 31. Notably, the typical reductive elimination from II was higher in energy and did not account for the observed diastereoselectivity. Reoxidation of the $\operatorname{Pd}(0)$ to the active $\operatorname{Pd}(\mathrm{II})$ catalyst was carried out in the presence of $\mathrm{Cu}(\mathrm{OAc})_{2}$ and $\mathrm{O}_{2}$. Several monosubstituted 1,3-dienes and electron-rich and electron-poor aromatic rings of phenethyltriflamides were tolerated. Interestingly, the reaction of $\alpha$-substituted phenethyltriflamides was completely diastereoselective as compared to $\beta$ substituted with only a 3:1 ratio of diastereomers. 

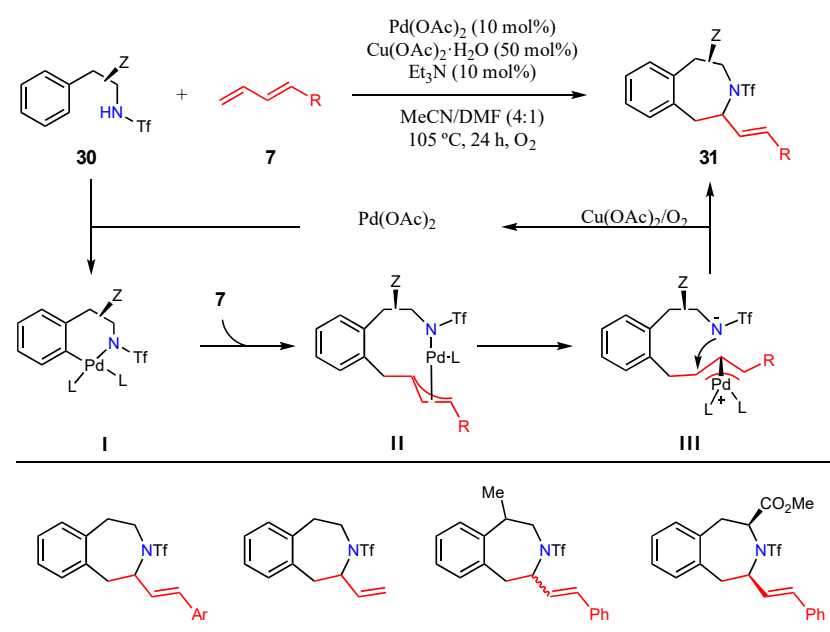

(NThe

1

$60-95 \%$

$60 \%$

$80 \%$
$\mathrm{dr}=3: 1$

$50 \%$
$\mathrm{dr}=>20: 1$

2 Scheme 12. Pd-catalyzed (5+2) annulation of phenethyl

3 triflamides and 1,3-dienes to 3-benzazepines. 28

29

In 2015, Li and co-workers reported a tandem $\mathrm{Rh} 30$ 5 catalyzed $(3+2) /(5+2)$ heteroannulation of 4-aryl

6 tosyltriazoles $\mathbf{3 2}$ with alkynes $\mathbf{2}$ to yield 3-

7 benzazepines 33 (Scheme 13). ${ }^{[50]}$ The author 31

8 proposed a mechanism that starts with the generation 2

9 of the Rh-carbenoid intermediate $\mathbf{I}$. The addition of a $\mathrm{a} 3$

10 alkyne affords a zwitterionic species II which4

11 undergoes an electrophilic cyclization to give the five 35

12 membered ring intermediate III $([3+2]$ annulation $) 36$

13 Then, a second $(5+2)$ annulation with the alkyne lead37

14 to the 3-benzazepine intermediate IV (via a transien 88

$15 \mathrm{Rh}-\mathrm{H}$ species) that evolves in two different pathway 39

16 depending on the substituents of the alkyne. Wher 40

17 aromatic alkynes are used, cleavage of the $\mathrm{C}-\mathrm{Rh}$ bon $\mathrm{Al}$

18 with the aid of $\mathrm{Cu}(\mathrm{OAc})_{2}$ through hydration with $\mathrm{H}_{2} \mathrm{OH} 2$

19 (or ROH) affords the benzylic alcohol and regenerat 43

20 the active $\mathrm{Rh}(\mathrm{III})$ catalyst. On the other hand, whet44

21 aliphatic alkynes are used, C-Rh bond is cleaved b45

$22 \mathrm{Cu}(\mathrm{OAc})_{2}$ followed by a $\beta$-hydride elimination to giv 46

23 the exo-methylene 3-benzazepine 34. A variety of

24 substituents on the aryl ring and symmetrically and

25 asymmetrically substituted alkyl/aryl alkynes were

26 well tolerated to give fairly good yields of the

27 corresponding 3-benzazepines.
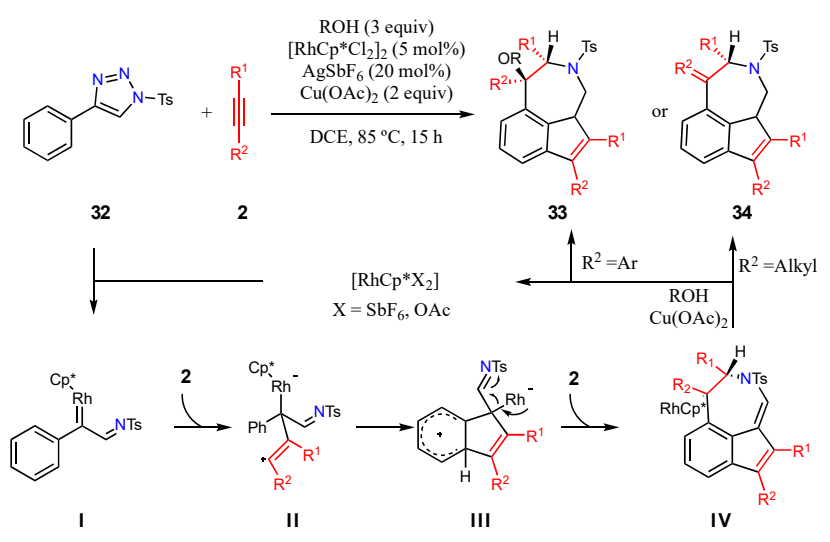

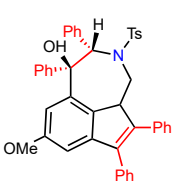

$69 \%$

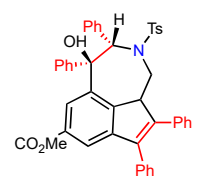

$60 \%$

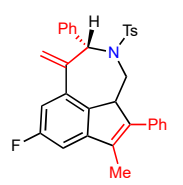

$62 \%$

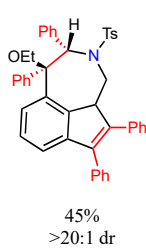

Scheme 13. Tandem Rh-catalyzed $(3+2) /(5+2)$ annulation of 4-aryl tosyltriazoles and alkynes to 3-benzazepines.

In 2017, Darses and co-workers reported an intriguing enantioselective Rh-catalyzed $(5+2)$ annulation of yne-enoate derivatives 35 with arylboronic acids 36 to yield 3-benzazepines 37 (Scheme 14). ${ }^{[51]}$ The authors suggested a mechanistic pathway that involves transmetallation of the arylboron reagent to the hydroxo $\mathrm{Rh}(\mathrm{I})$ complex followed by regioselective alkyne insertion to give a vinylrhodium intermediate $\mathbf{I}$. Then, 1,4-rearrangement (C-H activation) occurs to give an arylrhodium species II that undergo a conjugated addition to the enoate to deliver, after hydrolysis, the 3-benzazepine 37 with the concomitant regeneration of the active $\mathrm{Rh}(\mathrm{I})$ catalyst. Halogenated, electron-rich and electron-poor arylboronic acids were well tolerated giving fairly good yields of the corresponding 3-benzazepines.

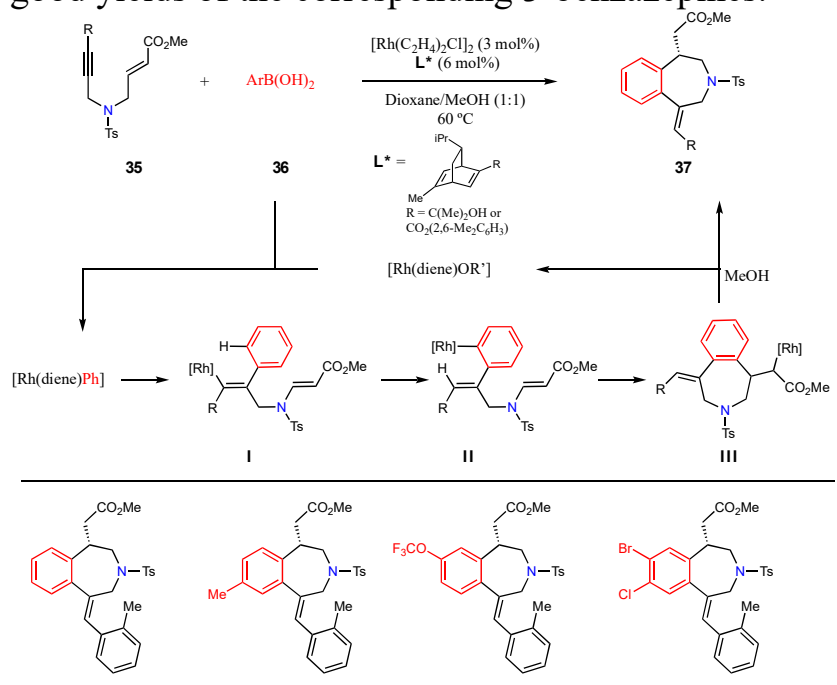

$61 \%, 86 \%$ ee

$84 \%, 82 \%$ ee

$87 \%, 98 \%$ ee

$78 \%, 97 \%$ ee

48 Scheme 14. Rh-catalyzed (5+2) annulation of yne-enoate 


\section{Benzodiazepines via Transition-Metak9}

2 Catalyzed Oxidative Annulations

\section{3.1 1,2-Benzodiazepines}

4

5

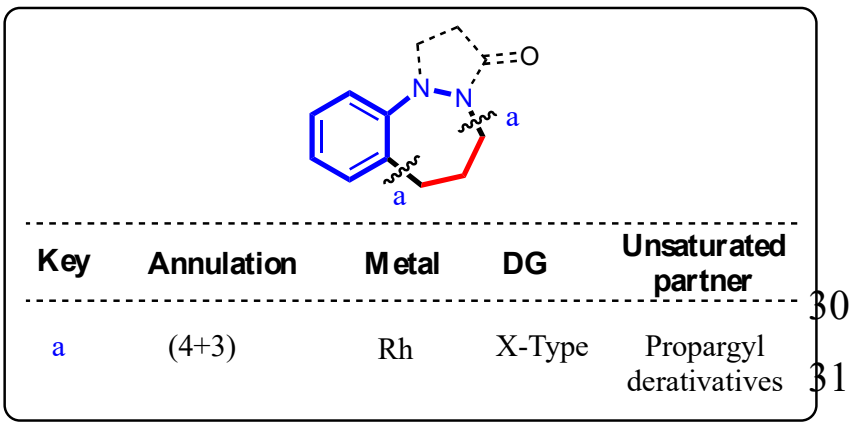

6 Figure 6. 1,2-Benzodiazepine disconnection

Very recently, the groups of Chauvin/Cui ${ }^{[52]}$ and 5 8 Zhang/Fan ${ }^{[33]}$ reported the Rh-catalyzed $(4+3) 6$

9 heteroannulation of $\mathrm{N}$-arylpyrazolidinones $\mathbf{3 8}$ and 7

10 propargyl derivatives 39 to 1,2-benzodiazepines $\mathbf{4 9 8}$

11 (Scheme 15). The proposed mechanism involves the 9

12 initial formation of the five- membered rhodacycle 40

13 through the coordination of the pyrazolidinone te 1

14 activate the o-C-H bond (via CMD). Theny2

15 coordination of the alkyne followed by regioselective 3

16 1,2-insertion (attributed to the oxygen coordination) 44

17 affords the seven-membered rhodacycle II. Finally45

18 protonolysis of the $\mathrm{C}-\mathrm{Rh}$ bond (III) followed by46

19 nucleophilic substitution delivers the 1,2-benzazepine47

2040 with regeneration of the active catalyst. Electron 48

21 rich and electron-poor substituents on the aryl ring of 9

22 the pyrazolidinone were well-tolerated as well a wids0

23 range of substituted propargylic derivatives.
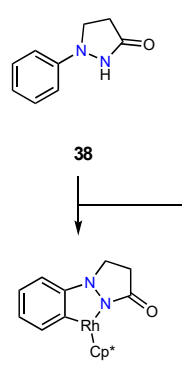<smiles>CC1(C)C=C(c2ccccc2)c2cc(Cl)ccc2N2CCC(=O)N21</smiles>

$82 \%$ $\left[\mathrm{Cp}^{*} \mathrm{RhCl}_{2}\right]_{2}(2.5 \mathrm{~mol} \%)$
$\mathrm{NaOAc}(1$ equiv)
$\mathrm{DCE}, 100^{\circ} \mathrm{C}$ air $\left[\mathrm{Cp}^{\mathrm{RhCl}} \mathrm{Rh}_{2}\right]_{2}(2.5 \mathrm{~mol} \%)$ $\mathrm{Zn}(\mathrm{OAc})_{2}(50 \mathrm{~mol} \%)$

$39 \quad \begin{gathered}\mathrm{NaOAc}(50 \mathrm{~mol}) \\ \text { toluene, } 100{ }^{\circ} \mathrm{C} \text {, air }\end{gathered}$
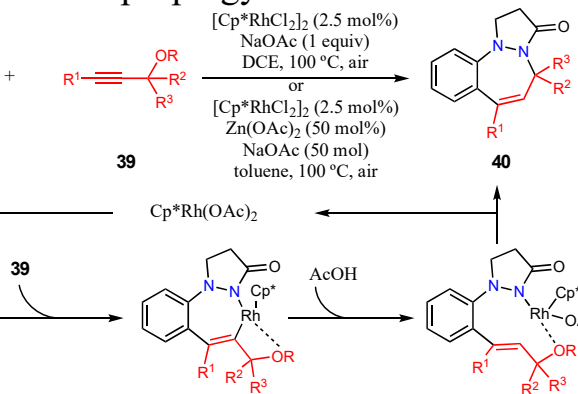

II
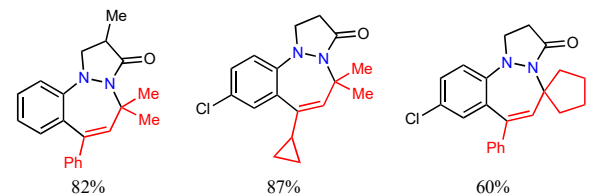

25 Scheme 15. Rh-catalyzed (4+3) annulation of $N$-aryl

26 pyrazolidinones and propargyl derivatives to 1,2-

27 benzodiazepines.

3.2 1,3-Benzodiazepines
51

53

\section{3}

1,3-Benzodiazepines have been synthesized under $\mathrm{Rh}$ catalysis using nitrogenated substrates bearing XType (ureas) ${ }^{[54]}$ and L-Type (guanidines) ${ }^{[55]}$ DGs via $(5+2)$ annulations (Figure 7).

In 2015, Zhou, Yang and co-workers reported a Rhcatalyzed $(5+2)$ heteroannulation of $N$ methoxycarbamoyl indolines $\mathbf{4 1}$ and aryl alkynes $\mathbf{2}$ to give 1,3-benzodiazepines 42 (Scheme 16). ${ }^{[54]}$ The proposed mechanism for this transformation involves the coordination of the $N$-methoxy urea DG to promote the $o-\mathrm{C}-\mathrm{H}$ activation (via CMD) with the generation of the six-membered rhodacycle I. Coordination and insertion of alkyne into $\mathrm{Rh}-\mathrm{C}$ bond affords the eightmembered rhodacycle II that, after reductive elimination, renders the $N$-methoxy 1,3benzodiazepine III. Oxidative addition of $\mathrm{Rh}(\mathrm{I})$ species to this $N$-methoxy derivative regenerates the Rh(III) active catalyst and releases the final 1,3benzodiazepine 42. A variety of indolines and aryl alkynes were well tolerated whereas aliphatic alkynes failed, providing isoquinolones as the major product (4+2 annulation).

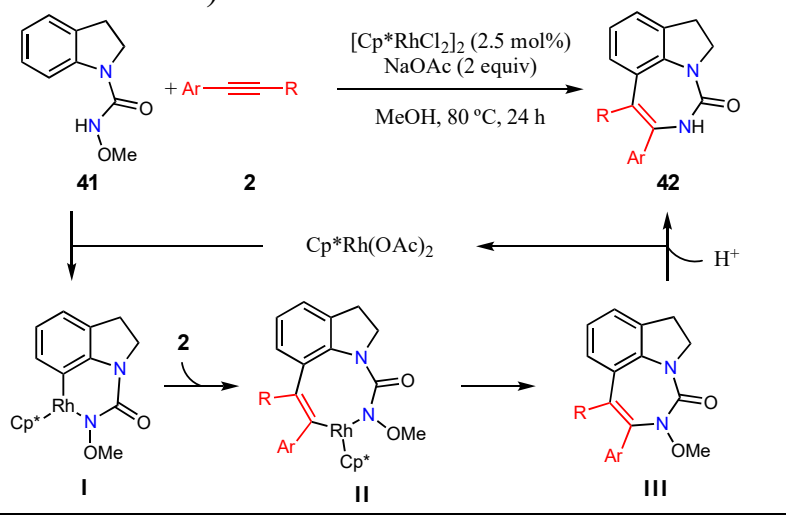

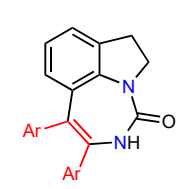

$65-80 \%$

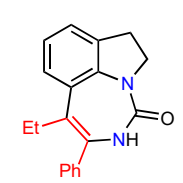

$54 \%$

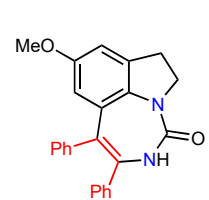

$80 \%$

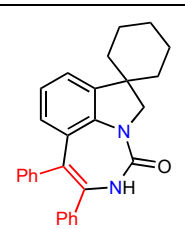

$60 \%$ 
1 Scheme 16. Rh-catalyzed $(5+2)$ annulation of N33

2 methoxycarbamoyl indolines and aryl alkynes to 1,3-

3 benzodiazepines.

4 Recently, Saá and co-workers reported the Rh5 catalyzed $(5+2)$ heteroannulation of cyclic 6 arylguanidines $\mathbf{4 3}$ and alkynes 2 to give 1,37 benzodiazepines 44 (Scheme 17). ${ }^{[55]}$ The use of $\mathrm{O}_{2}$

8 (method B) as the sole oxidant in place of typical metal

9 oxidants, like AgOAc (method A), clearly improves 4

10 the efficiency of the oxidative annulation. The striking

11 mechanism for this $(5+2)$ annulation was supported by5

12 DFT calculations. When AgOAc was used, the $\mathrm{C}-\mathrm{H}$

13 bond activation follows a classic CMD path

14 (energetically favored) to give the six-membere $B 6$

15 rhodacycle I whereas, in the case of $\mathrm{O}_{2}$, a $S_{E} A r$ path i37

16 favored. Coordination and 1,2- migratory insertion oB8

17 alkyne into $\mathrm{Rh}-\mathrm{C}$ bond affords the eight-membere $\mathrm{B} 9$

18 rhodacycle II. Curiously, the typical reductive 0

19 elimination step was higher in energy than th $\mathbb{1}$

20 decoordination of the benzimidazole moiety an $\mathbb{2} 2$

21 subsequent $\mathrm{S}_{\mathrm{N}} 2$ attack to the cationic $\mathrm{Rh}$ species that3

22 releases the 1,3-benzodiazepine 44. Exergoni\&4

23 deprotonation and reoxidation of $\mathrm{Rh}(\mathrm{I})$ to $\mathrm{Rh}(\mathrm{III})$ wast5

24 more favorable for $\mathrm{O}_{2}$ as compared to AgOAc. $\$ 6$

25 variety of electronically substituted indolines as wel47

26 as both aromatic and aliphatic alkynes gave good t\&8

27 excellent yields of 1,3-benzodiazepines under the tw 49

28 oxidative conditions employed.

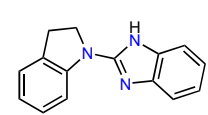

43

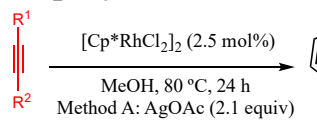

2 Method B: $\mathrm{O}_{2}$

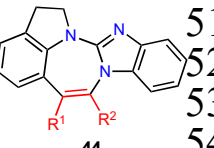

44
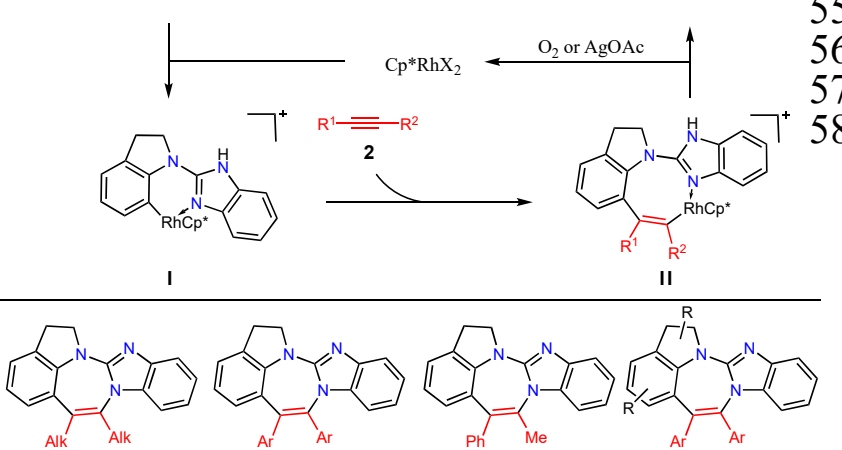

Method A : $47-60 \%$ Method B : $81-85 \%$

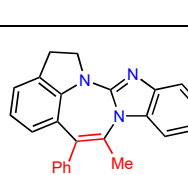
II

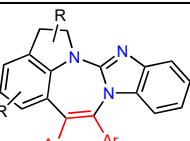

Method A: $66 \%$ Method B: $75 \%$ 1.5:1

Method A: $60-73 \%$ Method B: $85-90 \%$ Method A: $36-88 \%$
Method B: $75-93 \%$

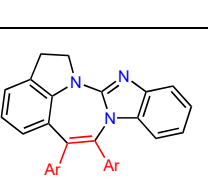

30 Scheme 17. Rh-catalyzed $(5+2)$ annulation of cyclic arylguanidines and alkynes to 1,3-benzodiazepines.

\section{3.3 1,5-Benzodiazepines}

60 Scheme 18. Pd-catalyzed $(5+2)$ annulation of $o$ -

61 indoloanilines and alkynes to 1,5-benzodiazepines.

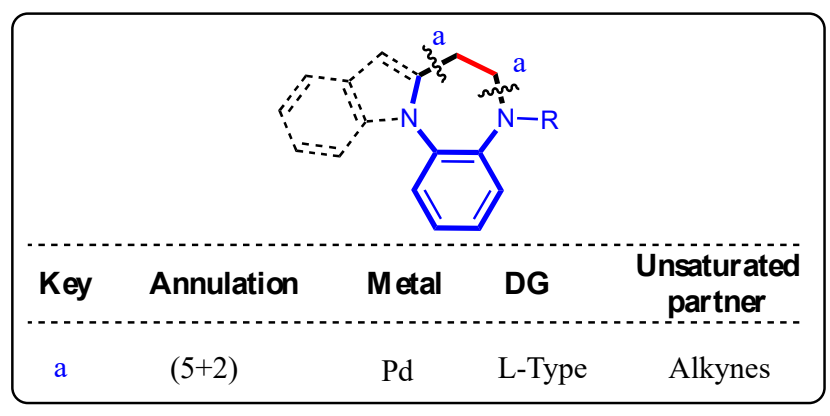

Figure 8. 1,5-Benzodiazepine disconnection

In 2017, Sun and co-workers reported the Pdcatalyzed (5+2) annulation of $o$-indoloanilines $\mathbf{4 5}$ and alkynes 2 to yield 1,5-benzodiazepines 46 (Scheme 18). ${ }^{[56]}$ The authors propose a mechanism for this annulation similar to the one made by Luan for the case of $o$-arylanilines. ${ }^{[37]}$ It is initiated with an anilineassisted (L-type DG) C-H bond activation (via CMD) of the $2 \mathrm{H}$-indole to form the dimeric six-membered palladacycle I. This dimeric complex is broken in the presence of the alkyne to form the coordinated species that undergoes 1,2-migratory insertion into the C-Pd bond to give an eight-membered palladacycle II. Subsequent C-N reductive elimination delivers the enamine 1,5-benzodiazepine III and concomitantly regenerates the $\mathrm{Pd}(\mathrm{II})$ to restart the catalytic cycle. Finally, tautomerization of the enamine to the thermodynamically more stable imine leads to the final 1,5-benzodiazepine 46. Other $o$-heteroarylanilines like $o$-pyrroloanilines and $o$-imidazoloanilines led to the corresponding 1,5-benzodiazepines in moderate to good yields. Both electron-rich and electron-poor indole rings and aromatic alkynes afford the corresponding 1,5-benzodiazepines in good yields.
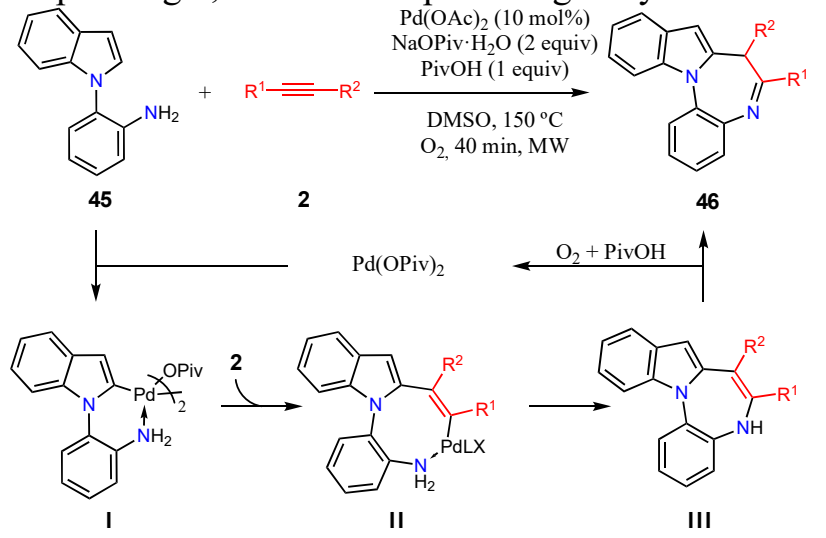

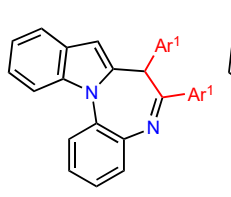

$58-87 \%$

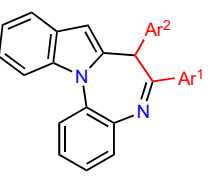

$27-60 \%$

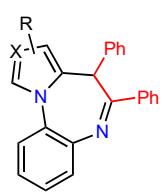

$50-76 \%$
$\mathrm{X}=\mathrm{C}, \mathrm{N}$

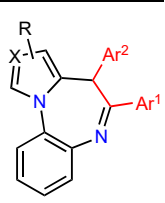

$38-65 \%$
$\mathrm{X}=\mathrm{C}, \mathrm{N}$ 


\section{$1 \quad 3.4$ 2,3-Benzodiazepines}

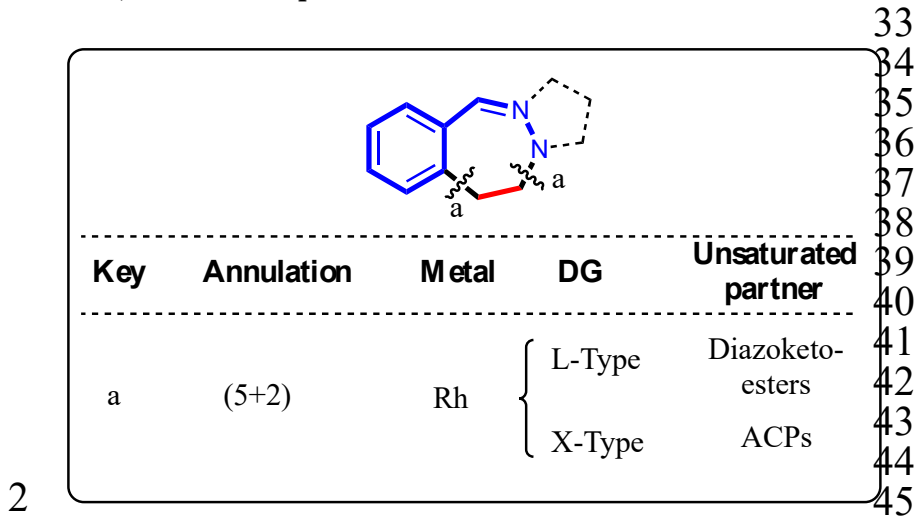

3 Figure 9. 2,3-Benzodiazepines disconnection

4 5 6 hydrazones 47 and diazoketoesters 48 to 2,37 benzadiazepines 49 (Scheme 19). ${ }^{[57]}$ As related 8 antecedents, the proposed mechanism involves the 9 initial formation of the five-membered rhodacycle I 10 through the coordination of the $N$-Boc hydrazone to 11 activate the $o-\mathrm{C}-\mathrm{H}$ bond (via CMD). Then, 12 coordination of the carbene would afford a $\mathrm{Rh}$-carbene 13 that undergoes a 1,1-migratory insertion to afford the 14 six-membered rhodacycle II. Subsequent protonolysis 15 of the $\mathrm{C}-\mathrm{Rh}$ bond releases the transient ketone III and 16 regenerates the active catalyst. Finally, a sequence 17 involving intramolecular $\mathrm{C}-\mathrm{N}$ cyclization, N-H 18 deprotonation leading to the $\mathrm{C}=\mathrm{N}$ double bond (IV) 19 and $N$-Boc cleavage delivers the final product 49. The 20 reaction tolerated electron-rich and electron-poor 21 substituents on the aryl ring of the $N$-Boc hydrazone, 22 as well as alkyl substituents both on the benzaldimine 23 and on the diazoketoester.

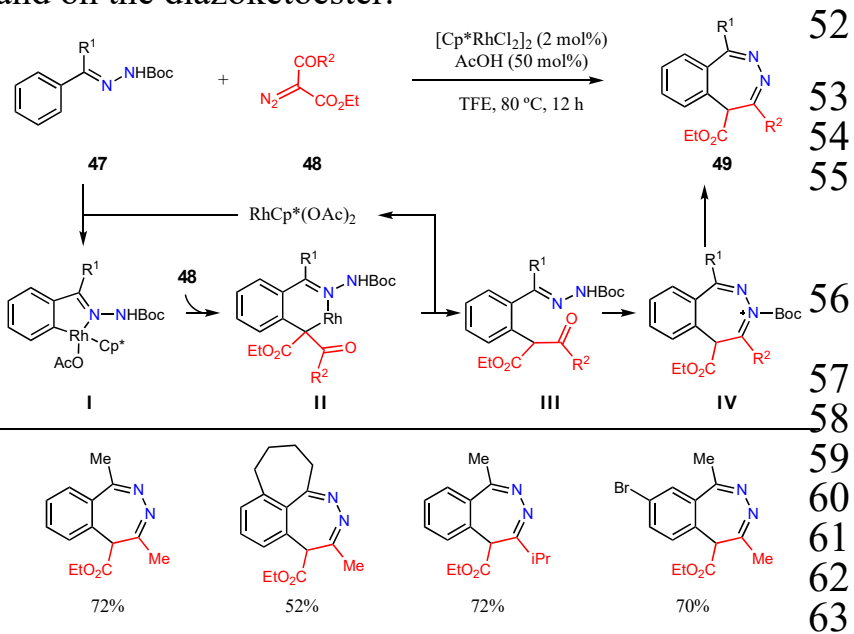

Scheme 19. Rh-catalyzed $(5+2)$ annulation of $N$-Bo 64 hydrazones and diazoketoesters to 2,3-benzodiazepines.

In 2018, Bai, $\mathrm{Li}$ and co-workers reported the $\mathrm{Rh}-68$

29 catalyzed $(5+2)$ heteroannulation of azomethine

30 bicyclic 2,3-benzodiazepines $\mathbf{5 2}$ (Scheme 20). ${ }^{[58]}$ The 1

31 proposed mechanism involves the initial formation of ${ }^{2}$
2 the six-membered rhodacycle I through the coordination of the azomethine imines to activate the o-C-H bond (via CMD). ${ }^{[58]}$ The proposed mechanism involves the initial formation of the six-membered rhodacycle I through the coordination of the azomethine imines to activate the $\mathrm{o}-\mathrm{C}-\mathrm{H}$ bond (via CMD). Then, coordination of the ACP and subsequent regioselective 1,2-migratory insertion of the $\mathrm{Rh}$-aryl bond provides the cyclopropyl $\mathrm{Rh}$ intermediate II, which undergoes a $\beta-C$ elimination to afford the $\mathrm{Rh}$ alkyl species III. Subsequent $\beta-\mathrm{H}$ elimination followed by reductive elimination affords the transient 1,3-diene IV with the concomitant recovery of the active $\mathrm{Rh}(\mathrm{III})$ catalyst after oxidation with $\mathrm{AgOAc}$. 6 Finally, an intramolecular $(3+2)$ cycloaddition delivers 47 the bicyclic 2,3-benzodiazepine 52. Electron-rich and 48 electron-poor substituents either on the aryl ring of the azomethine imine or on the ACP were well tolerated giving fairly good yields and diastereoselectivities $(>20: 1)$.

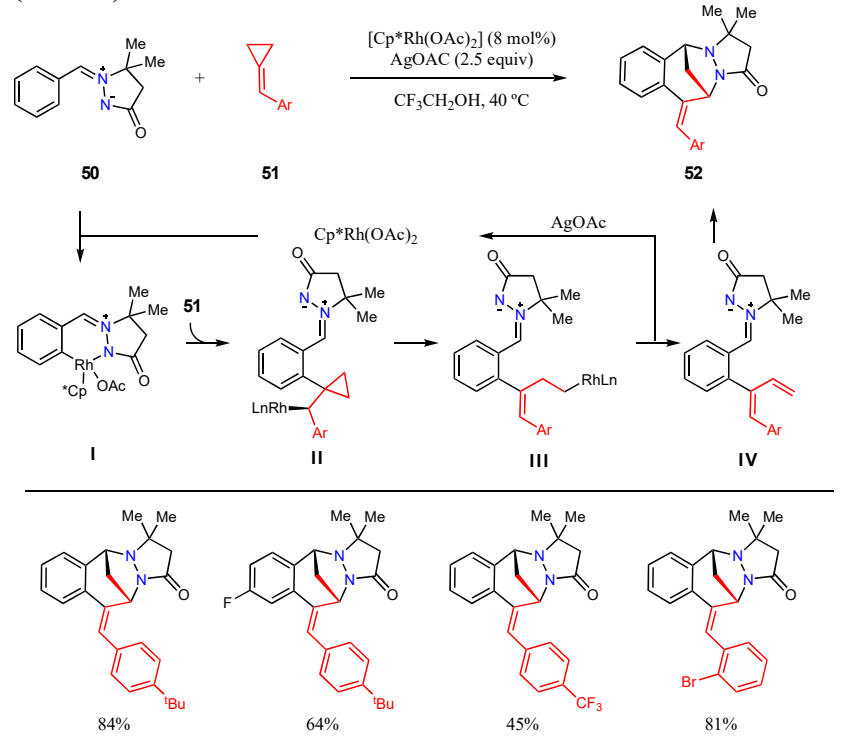

Scheme 20. Rh-catalyzed $(5+2)$ heteroannulation of azomethine imines and ACP to bicyclic 2,3benzodiazepines.

\section{Summary and Outlook}

Transition-metal catalyzed annulation reactions that involve the direct activation of aromatic $\mathrm{C}-\mathrm{H}$ bonds are among the most elegant and environmentally friendly methods to construct azaheterocyclic compounds. Regioselectivity (ortho activation) is commonly addressed by using substrates that bear L-type and Xtype DGs capable of precoordinating the metal catalyst. In this review we have described the state-of-the-art advances in the transition-metal catalyzed annulations via $\mathrm{C}-\mathrm{H}$ bond activation to synthesize benzofused seven-membered azaheterocycles, benzazepines and benzodiazepines, whose members typically show potent and useful biological/pharmacological properties.

The difficulty to obtain seven-membered azaheterocycles using this sustainable methodology 
1 compared to five- or six-membered analogs, and th 67

2 large synthetic application of this type of compound58

3 makes their synthetic exploration an emerging field59

4 Indeed, it is necessary to increase the availability of 0

5 seven-membered azaheterocycles in the pharm 1

6 pipeline. These new synthetic methodologies oper62

7 access to valuable drug-like scaffolds with many63

8 potential therapeutic targets. Future work shoul $\$ 4$

9 provide new DGs, coupling partners and mechanistig5

10 insights to expand the synthetic toolbox towar8 86

11 bioactive azaheterocycles. In addition, total synthesis7

12 and industrial application of selected members, e. $g_{68}$

13 1,4-benzodiazepines, and the use of more-abundanf 8

14 metals than $\mathrm{Pd}$ and $\mathrm{Rh}$ as catalysts should b 70

15

\section{Acknowledgements}

This work has received financial support from MINECO (projec7 6 CTQ2017-87939R and ORFEO-CINQA network RED201877 102387-T), the Xunta de Galicia (project ED431C 2018/04 and 8 Centro singular de investigación de Galicia accreditation 2019-8 2022, ED431G 2019/03) and the European Union (European Re79 gional Development Fund - ERDF). A.V.-R. thanks Xunta de Ga80

\section{References}

[1] a) Balanol: P. Kulanthaivel, Y. F. Hallock87 C. Boros, S. M. Hamilton, W. P. Janzens8 L. M. Ballas, C. R. Loomis, J. B. Jiang, B89 Katz, J. R. Steiner, J. Clardy, J. Am. Chem90 Soc. 1993, 115, 6452-6453; b) V. Pande91 M. J. Ramos, F. Gago, Anti-Cancer Agents2 Med. Chem. 2008, 8, 638-645; c) X. He93 M. Zhang, Y.-Y. Guo, X.-M. Mao, X.-A94 Chen, Y.-Q. Li, Org. Lett. 2018, 20, 632395 6326; d) Stemmona alkaloids: R. A. Pillig6 G. B. Rosso, M. d. C. Ferreira de Oliveira97 Nat. Prod. Rep. 2010, 27, 1908-1937; eø8 M. C. McLeod, G. Singh, J. N. Plamping9 D. Rane, J. L. Wang, V. W. Day, J. Aubéø0 Nat. Chem. 2014, 6, 133-140; f) H. Gregథ01 Phytochem. Rev. 2019, 18, 463-493; g) X02 Yin, K. Ma, Y. Dong, M. Dai, Org. Letto3 2020, 22, 5001-5004; h) Chalciporone: P04 Spiteller, D. Hamprecht, W. Steglich, $\Psi_{05}$ Am. Chem. Soc. 2001, 123, 4837-4838. 106

[2] V. J. Ram, A. Sethi, R. Pratap, in "Sevene7 Membered Heterocycles", The Chemistno8 of Heterocycles Elsevier, 2019, pp. 39309 425.

[3] a) J. B. Bremner, S. Samosorn, in 1 "Azepines and their Fused-ring 2 Derivatives", Comprehensixq 3 Heterocyclic Chemistry III, Vol. 13 (Eds.14 A. R. Katrizky, C. A. Ramsden, R. J. K15 Taylor), Elsevier, 2008, pp. 1-43, and licia for a predoctoral fellowship (ED481A-2018/34, 2018-2021) 81 references therein; b) L. Yet, in "Benzodiazepines", Privileged Structures in Drug Discovery, Wiley \& Sons, 2018, pp. 15-58.

[4] a) E. Vitaku, D. T. Smith, J. T. Njardarson, J. Med. Chem. 2014, 57, 10257-10274; b) L. Tan, W. Yan, J. D. McCorvy, J. Cheng, J. Med. Chem. 2018, 61, 9841-9878; c) S. Elangovan, A. Afanasenko, J. Haupenthal, Z. Sun, Y. Liu, A. K. H. Hirsch, K. Barta, ACS Cent. Sci. 2019, 5, 1707-1716.

[5] a) A. Zhang, J. L. Neumeyer, R. J. Baldessarini, Chem. Rev. 2007, 107, 274302 ; b) N. Ye, J. L. Neumeyer, R. J. Baldessarini, X. Zhen, A. Zhang, Chem. Rev. 2013, 113, 123-178; c) A. Hall, L. Provins, A. Valade, J. Med. Chem. 2019, 62, 128-140.

[6] a) J. Zhang, H. Zhang, W. Cai, L. Yu, X. Zhen, A. Zhang, Bioorg. Med. Chem. 2009, 17, 4873-4880; b) G. A. Higgins, P. J. Fletcher, ACS Chem. Neurosci. 2015, 6, 1071-1088.

[7] a) P. Yin, N. Zheng, J. Dong, C. Xu, X. Zhang, G. Ding, Oncol. Lett. 2019, 17, 1177-1183; b) T. Watanabe, Y. Sato, H. M. A. A. Masud, M. Takayama, H. Matsuda, Y. Hara, Y. Yanagi, M. Yoshida, F. Goshima, T. Murata, H. Kimura, Cancer Sci. 2020, 111, 279-287.

[8] E. Simoni, S. Daniele, G. Bottegoni, D. Pizzirani, M. L. Trincavelli, L. Goldoni, G. Tarozzo, A. Reggiani, C. Martini, D. Piomelli, C. Melchiorre, M. Rosini, A. Cavalli, J. Med. Chem. 2012, 55, 97089721.

[9] a) P. M. O'Neil, S. R. Smith, N. J. Weissman, M. C. Fidler, M. Sanchez, J. Zhang, B. Raether, C. M. Anderson, W. R. Shanahan, Obesity 2012, 20, 1426-1436; b) S. Z. Yanovski, J. A. Yanovski, JAMA, J. Am. Med. Assoc. 2014, 311, 74-86.

[10] N. Arora, P. Dhiman, S. Kumar, G. Singh, V. Monga, Bioorg. Chem. 2020, 97, 103668.

[11] a) B. J. Melancon, C. R. Hopkins, M. R. Wood, K. A. Emmitte, C. M. Niswender, A. Christopoulos, P. J. Conn, C. W. Lindsley, J. Med. Chem. 2012, 55, 14451464; b) D. Lemoine, R. Jiang, A. Taly, T. Chataigneau, A. Specht, T. Grutter, Chem. Rev. 2012, 112, 6285-6318; c) T. Clayton, M. M. Poe, S. Rallapalli, P. Biawat, M. M. Savic, J. K. Rowlett, G. Gallos, C. W. Emala, C. C. Kaczorowski, D. C. Stafford, L. A. Arnold, J. M. Cook, Int. J. Med. Chem. 2015, 430248-430302; d) E. Sigel, M. Ernst, Trends Pharmacol. Sci. 2018, 39, 659-671. 
1 [12] S. Solyom, I. Tarnawa, Curr. Pharm. Des60

2002, 8, 913-939.

[13] J. Mantaj, P. J. M. Jackson, K. M62 Rahman, D. E. Thurston, Angew. Chem63 2017, 129, 474-502; Angew. Chem. Int. Eه4 2017, 56, 462-488.

65

[14] a) D. S. Hewings, T. P. C. Rooney, L. E66 Jennings, D. A. Hay, C. J. Schofield, P. E67 Brennan, S. Knapp, S. J. Conway, J. Med68 Chem. 2012, 55, 9393-9413; b) G. Zhang69 S. G. Smith, M.-M. Zhou, Chem. Rev70 2015, 115, 11625-11668.

71

[15] a) R. Sakhuja, K. Bajaj, S. M. Abdu72 Shakoor, A. Kumar, Mini-Rev. Org. Chem7.3 2014, 11, 55-72; b) N. E. Calcaterra, J. C74 Barrow, ACS Chem. Neurosci. 2014, 575 253-260.

[16] a) C. E. Griffin, 3rd, A. M. Kaye, F. R77 Bueno, A. D. Kaye, Ochsner J. 2013, 1378 214-223; b) A. A. Elgarf, F. Steudle, P79 Scholze, A. A. Elgarf, D. C. B. Siebert, F80 Steudle, A. Draxler, M. Ernst, G. Li, S81 Huang, J. M. Cook, ACS Chem. Biol. 201\&2 13, 2033-2039.

[17] a) Q. Cai, H. Sun, Y. Peng, J. Lu, Z84 Nikolovska-Coleska, D. McEachern, L85 Liu, S. Qiu, C.-Y. Yang, R. Miller, H. Yi86 T. Zhang, D. Sun, S. Kang, M. Guo, L87 Leopold, D. Yang, S. Wang, J. Med. Chen88 2011, 54, 2714-2726; b) F. Benedetti, M.89 A. Perrin, S. Bosc, F. Chouteau, N90 Champion, A. Bigot, Org. Process Res91 Dev. 2020, 24, 762-768.

[18] V. A. Assimon, Y. Tang, J. D. Vargas, G93 J. Lee, Z. Y. Wu, K. Lou, B. Yao, M.-K94 Menon, A. Pios, K. C. Perez, A. Madriaga95 P. K. Buchowiecki, M. Rolfe, L. Shawver96 X. Jiao, R. Le Moigne, H.-J. Zhou, D. J97 Anderson, ACS Chem. Biol. 2019, 1498 236-244.

[19] R. Verma, R. Bhatia, G. Singh, B. Kumarn00 S. Mehan, V. Monga, Bioorg. Chem. 202(0,1 101, 104010.

[20] a) A. G. Meyer, A. C. Bissember, $\mathbb{C} 03$ Hyland, J. A. Smith, C. C. Williams, F04 Zamani, S.-A. G. Abel, in "Seven 05 Membered Rings", Progress 1106 Heterocyclic Chemistry, Vol. 29, Elsevierr07 2017, pp. 579-633; b) A. G. Meyer, A. $\mathbb{C} 08$ Bissember, C. J. T. Hyland, H. Pham, 1109 "Seven-Membered Rings", Progress in 0 Heterocyclic Chemistry, Vol. 30, Elseviedr1 1 2018, pp. 493-550; c) A. G. Meyer, A. $\mathbb{C} 12$ Bissember, C. J. T. Hyland, J. A. Smith, $\mathbb{C} 13$ C. Williams, M. Szabo, M. A. Pearsal, II14 K. Hyland, W. J. Olivier, in "Seven 15 Membered Rings", Progress 1116 Heterocyclic Chemistry, Vol. 31, Elseviedr17 2020, pp. 597-647.
[21]

a) 1-Benzazepines: L. Min, B. Pan, Y. Gu, Org. Lett. 2016, 18, 364-367; b) 2Benzazepines: T. O. Vieira, H. Alper, Org. Lett. 2008, 10, 485-487; c) P. Hasebein, K. Aulinger, D. Schepmann, B. Wuensch, Tetrahedron 2013, 69, 4552-4562; d) P. Hasebein, B. Frehland, K. Lehmkuhl, R. Froehlich, D. Schepmann, B. Wuensch, Org. Biomol. Chem. 2014, 12, 5407-5426; e) 3-Benzazepines: S. M. Husain, R. Froehlich, D. Schepmann, B. Wuensch, $J$. Org. Chem. 2009, 74, 2788-2793; f) 1,4BDZ: D. Antonow, D. E. Thurston, Chem. Rev. 2011, 111, 2815-2864; g) U. K. Sharma, N. Sharma, D. D. Vachhani, E. V. Van der Eycken, Chem. Soc. Rev. 2015, 44, 1836-1860; h) 1,5-BDZs: A. Pareek, N. Kumar, A. Agarwal, P. Sharma, D. Kishore, Res. J. Chem. Sci. 2013, 3, 90103; i) 2,3-BDZs: K. Okuma, Y. Tanabe, R. Itoyama, N. Nagahora, K. Shioji, Chem. Lett. 2013, 42, 1260-1262.

[22] a) 1-Benzazepines: D.-J. Cheng, H.-B. Wu, S.-K. Tian, Org. Lett. 2011, 13, 56365639; b) C. W. Suh, S. J. Kwon, D. Y. Kim, Org. Lett. 2017, 19, 1334-1337; c) 2Benzazepines: A. Kamimura, Y. Taguchi, Y. Omata, M. Hagihara, J. Org. Chem. 2003, 68, 4996-4998; d) M. So, T. Kotake, K. Matsuura, M. Inui, A. Kamimura, J. Org. Chem. 2012, 77, 4017-4028; e) 3Benzazepines: W.-D. Z. Li, X.-W. Wang, Org. Lett. 2007, 9, 1211-1214; f) K. Mori, K. Kurihara, S. Yabe, M. Yamanaka, T. Akiyama, J. Am. Chem. Soc. 2014, 136, 3744-3747; g) 1,4-BDZs: J. Yang, X. Che, Q. Dang, Z. Wei, S. Gao, X. Bai, Org. Lett. 2005, 7, 1541-1543; h) J.-Y. Wang, X.-F. Guo, D.-X. Wang, Z.-T. Huang, M.-X. Wang, J. Org. Chem. 2008, 73, 19791982; i) S. Wang, Y.-B. Shen, L.-F. Li, B. Qiu, L. Yu, Q. Liu, J. Xiao, Org. Lett. 2019, 21, 8904-8908; j) 2,3-BDZs: Y. Matsuya, N. Ohsawa, H. Nemoto, J. Am. Chem. Soc. 2006, 128, 13072-13073.

[23] a) 3-Benzazepines: G. Zhan, M.-L. Shi, Q. He, W. Du, Y.-C. Chen, Org. Lett. 2015, 17, 4750-4753; b) 1,4-BDZs: J. Shin, J. Lee, D. Ko, N. De, E. J. Yoo, Org. Lett. 2017, 19, 2901-2904.

[24] 3-Benzazepines: A. Gini, J. Bamberger, J. Luis-Barrera, M. Zurro, R. Mas-Ballesté, J. Alemán, O. G. Mancheño, Adv. Synth. Catal. 2016, 358, 4049-4056.

[25] a) 1-Benzazepines: H. Tabata, T. Yoneda, T. Tasaka, S. Ito, T. Oshitari, H. Takahashi, H. Natsugari, J. Org. Chem. 2016, 81, 3136-3148; b) 3-Benzazepines: S. G. Stewart, C. H. Heath, E. L. Ghisalberti, Eur. J. Org. Chem. 2009, 1934-1943; c) A. 
A. Peshkov, V. A. Peshkov, O. P61 Pereshivko, K. Van Hecke, R. Kumar, E62 V. Van der Eycken, J. Org. Chem. 201563 80, 6598-6608.

[26] a) 2-Benzazepines: N. Iqbal, A. Fiksdahl65 J. Org. Chem. 2013, 78, 7885-7895; b) 166 Benzazepines: C. Guo, M. Fleige, D67 Janssen-Mueller, C. G. Daniliuc, F68 Glorius, J. Am. Chem. Soc. 2016, 13869 7840-7843; c) L. Wang, S. Li, M. BluemeV,0 A. R. Philipps, A. Wang, R. Puttreddy, K71 Rissanen, D. Enders, Angew. Chem. 201672 128, 11276-11280; Angew. Chem. Int. Ed73 2016, 55, 11110-11114; d) Y. Li, M. Hu74 J.-H. Li, ACS Catal. 2017, 7, 6757-6761.75

[27] 1-Benzazepines: S. A. I. Sharif, E. D. D76 Calder, F. G. Delolo, A. Sutherland, J. Org.7 Chem. 2016, 81, 6697-6706.

[28] a) 1-Benzazepines: R. Wang, R.-X. Jin79 Z.-Y. Qin, K.-J. Bian, X.-S. Wang, Chem80 Commun. 2017, 53, 12229-12232; b) FoB1 a Pd-catalyzed homocoupling o 82 benzamides to dibenzo[c,e]azepine-5,783 diones, see: V. Kondapalli, X. Yu, Y84 Yamamoto, M. Bao, J. Org. Chem. 201785 82, 2288-2293.

[29] a) 2-Benzazepines: C. Bressy, D. Alberico87 M. Lautens, J. Am. Chem. Soc. 2005, 12788 13148-13149; b) Indolo-2-benzazepines89 Y. Xie, Y. Zhao, B. Qian, L. Yang, C. Xia90 H. Huang, Angew. Chem. 2011, 12391 5800-5804; Angew. Chem. Int. Ed. 201192 50, 5682-5686; c) 1,4-BDZs: J. D93 Neukom, A. S. Aquino, J. P. Wolfe, Org94 Lett. 2011, 13, 2196-2199; d) P. Kundu, A95 Mondal, B. Das, C. Chowdhury, Adv96 Synth. Catal. 2015, 357, 3737-3752; e97 1,5-BDZs: M. Weers, L. H. Luehning, V98 Luehrs, C. Brahms, S. Doye, Chem. Eur99 J. 2017, 23, 1237-1240.

[30] a) 1,4-BDZs: V. R. Jumde, E. Cini, A01 Porcheddu, M. Taddei, Eur. J. Org. Cherh02 2015, 1068-1074; b) V. Murugesh, B03 Harish, M. Adiseshu, J. Babu Nanubolu, 1894 Suresh, Adv. Synth. Catal. 2016, 35805 1309-1321.

106

[31] a) 3-Benzazepines: L. Zhang, D. Ye, Y07 Zhou, G. Liu, E. Feng, H. Jiang, H. Liu, 1008 Org. Chem. 2010, 75, 3671-3677; b) A09 Álvarez-Pérez, C. González-Rodríguez, 1.0 García-Yebra, J. A. Varela, E. Oñate, M11 1 A. Esteruelas, C. Saá, Angew. Chem. 20115,2 127, 13555-13559; Angew. Chem. Int. Ed13 2015, 54, 13357-13361.

114

[32] G. A. Molander, Acc. Chem. Res. 1998, 3115 603-609.

116

[33] a) N. Kuhl, M. N. Hopkinson, J. Wencell17 Delord, F. Glorius, Angew. Chem. 201218 124, 10382-10401; Angew. Chem. Int. Ed. 2012, 51, 10236-10254; b) Z. Chen, B.
Wang, J. Zhang, W. Yu, Z. Liu, Y. Zhang, Org. Chem. Front. 2015, 2, 1107-1295; c) R.-Y. Zhu, M. E. Farmer, Y.-Q. Chen, J.Q. Yu, Angew. Chem. 2016, 128, 1073410756; Angew. Chem. Int. Ed. 2016, 55, 10578-10599; d) J. He, M. Wasa, K. S. L. Chan, Q. Shao, J.-Q. Yu, Chem. Rev. 2017, 117, 8754-8786; e) X. Qi, Y. Li, R. Bai, Y. Lan, Acc. Chem. Res. 2017, 50, 27992808; f) P. Gandeepan, L. Ackermann, Chem 2018, 4, 199-222; g) C. Sambiagio, D. Schönbauer, R. Blieck, T. Dao-Huy, G. Pototschnig, P. Schaaf, T. Wiesinger, M. F. Zia, J. Wencel-Delord, T. Besset, B. U. W. Maes, M. Schnürch, Chem. Soc. Rev. 2018, 47, 6603-6743; h) For a book, see: X.-F. Wu, Transition Metal-Catalyzed Heterocycle Synthesis via C-H Activation, Wiley-VCH, Winheim, 2016.

[34] M. Gulías, J. L. Mascareñas, Angew. Chem. 2016, 128, 11164-11184; Angew. Chem. Int. Ed. 2016, 55, 11000-11019.

[35] L. Wang, J. Huang, S. Peng, H. Liu, X. Jiang, J. Wang, Angew. Chem. 2013, 125, 1812-1816; Angew. Chem. Int. Ed. 2013, 52, 1768-1772.

[36] However simple anilide derivatives gave $[3+2]$ oxidative annulations to indols D. R. Stuart, M. Bertrand-Laperle, K. M. N. Burgess, K. Fagnou, J. Am. Chem. Soc. 2008, 130, 16474-16475.

[37] Z. Zuo, J. Liu, J. Nan, L. Fan, W. Sun, Y. Wang, X. Luan, Angew. Chem. 2015, 127, 15605-15609; Angew. Chem. Int. Ed. 2015, 54, 15385-15389.

[38] L. Bai, Y. Wang, Y. Ge, J. Liu, X. Luan, Org. Lett. 2017, 19, 1734-1737.

[39] B. Cendón, N. Casanova, C. Comanescu, R. García-Fandiño, A. Seoane, M. Gulías, J. L. Mascareñas, Org. Lett. 2017, 19, 1674-1677.

[40] L. Wu, Y. Meng, J. Ferguson, L. Wang, F. Zeng, J. Org. Chem. 2017, 82, 4121-4128.

[41] H. He, W.-B. Liu, L.-X. Dai, S.-L. You, Angew. Chem. 2010, 122, 1538-1541; Angew. Chem. Int. Ed. 2010, 49, 14961499.

[42] G.-W. Wang, J. F. Bower, J. Am. Chem. Soc. 2018, 140, 2743-2747.

[43] Z. Shi, C. Grohmann, F. Glorius, Angew. Chem. 2013, 125, 5503-5507; Angew. Chem. Int. Ed. 2013, 52, 5393-5397.

[44] S. Cui, Y. Zhang, D. Wang, Q. Wu, Chem. Sci. 2013, 4, 3912-3916.

[45] A. K. Pandey, S. H. Han, N. K. Mishra, D. Kang, S. H. Lee, R. Chun, S. Hong, J. S. Park, I. S. Kim, ACS Catal. 2018, 8, 742746. 
1 [46] M. Martínez-Mingo, N. Rodríguez, R22

2 Gómez Arrayás, J. C. Carretero, Org. Lett23

[47] For a stoichiometric Pd [6+125 carbonylation to 2-benzazepinones, see: $\mathrm{R} 6$ Frutos-Pedreno, E. García-Sánchez, M. J27 Oliva-Madrid, D. Bautista, E. Martínezz8 Viviente, I. Saura-Llamas, J. Vicente29 Inorg. Chem. 2016, 55, 5520-5533. 30

[48] A. Rodríguez, J. Albert, X. Ariza, J31 García, J. Granell, J. Farrás, A. La Mela32 E. Nicolás, J. Org. Chem. 2014, 79, 957833 9585.

[49] Á. Velasco-Rubio, J. A. Varela, C. Saá35 Org. Lett. 2020, 22, 3591-3595. 36

[50] Y. Yang, M.-B. Zhou, X.-H. Ouyang, R37 Pi, R.-J. Song, J.-H. Li, Angew. Chem38 2015, 127, 6695-6699; Angew. Chem. Int 39 Ed. 2015, 54, 6595-6599.

[51] A. Claraz, F. Serpier, S. Darses, ACS Catal. 2017, 7, 3410-3413.
[52] T. Li, Z. Yang, Z. Song, R. Chauvin, X. Cui, Org. Lett. 2020, 22, 4078-4082.

[53] L. Zhang, Y. Xu, X. Zhang, X. Zhang, X. Fan, Org. Chem. Front. 2020, 7, 22842290.

[54] X. Wang, H. Tang, H. Feng, Y. Li, Y. Yang, B. Zhou, J. Org. Chem. 2015, 80, 6238-6249.

[55] N. Martínez-Yañez, J. Suárez, A. Cajaraville, J. A. Varela, C. Saá, Org. Lett. 2019, 21, 1779-1783.

[56] T. U. Thikekar, C.-M. Sun, Adv. Synth. Catal. 2017, 359, 3388-3396.

[57] J. Wang, L. Wang, S. Guo, S. Zha, J. Zhu, Org. Lett. 2017, 19, 3640-3643.

[58] D. Bai, T. Xu, C. Ma, X. Zheng, B. Liu, F. Xie, X. Li, ACS Catal. 2018, 8, 4194-4200. 


\section{REVIEW}

Recent Advances in Transition-Metal Catalyzed Oxidative Annulations to Benzazepines and

Benzodiazepines

Adv. Synth. Catal. Year, Volume, Page - Page

Álvaro Velasco-Rubio, Jesús A. Varela and Carlos Saá*

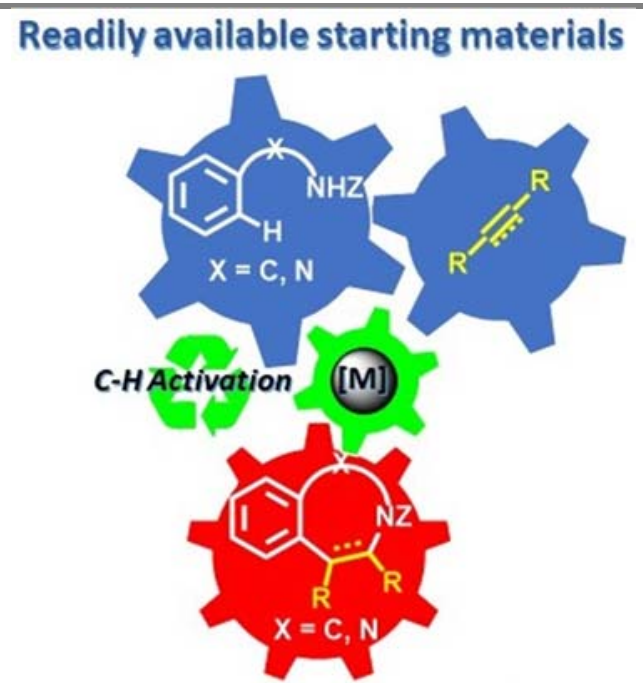

Benzazepines \& Benzodiazepines 